\title{
Perovskite Solar Cells: Progress and Advancements
}

\author{
Naveen Kumar Elumalai *, Md Arafat Mahmud, Dian Wang and Ashraf Uddin * \\ School of Photovoltaic and Renewable Energy Engineering, University of New South Wales, \\ Sydney 2052, Australia; mdarafat.mahmud@unsw.edu.au (M.A.M.); dian.wang@unsw.edu.au (D.W.) \\ * Correspondence: n.elumalai@unsw.edu.au (N.K.E.); a.uddin@unsw.edu.au (A.U.); Tel.: +61-2-9385-9827 (A.U.) \\ Academic Editor: Jean-Michel Nunzi \\ Received: 26 August 2016; Accepted: 19 October 2016; Published: 25 October 2016
}

\begin{abstract}
Organic-inorganic hybrid perovskite solar cells (PSCs) have emerged as a new class of optoelectronic semiconductors that revolutionized the photovoltaic research in the recent years. The perovskite solar cells present numerous advantages include unique electronic structure, bandgap tunability, superior charge transport properties, facile processing, and low cost. Perovskite solar cells have demonstrated unprecedented progress in efficiency and its architecture evolved over the period of the last 5-6 years, achieving a high power conversion efficiency of about $22 \%$ in 2016, serving as a promising candidate with the potential to replace the existing commercial PV technologies. This review discusses the progress of perovskite solar cells focusing on aspects such as superior electronic properties and unique features of halide perovskite materials compared to that of conventional light absorbing semiconductors. The review also presents a brief overview of device architectures, fabrication methods, and interface engineering of perovskite solar cells. The last part of the review elaborates on the major challenges such as hysteresis and stability issues in perovskite solar cells that serve as a bottleneck for successful commercialization of this promising PV technology.
\end{abstract}

Keywords: Perovskite photovoltaics; electronic structure; crystal structure; stability; hysteresis; interface engineering

\section{Introduction}

Recent advances in organic-inorganic hybrid perovskite solar cells (PSCs) with methyl ammonium lead iodide as the archetypal material, have led to the advent of new low cost photovoltaic (PV) technology that could be a viable competitor to the commercially available Silicon based solar cells $[1,2]$. Apart from low cost, simple device processing and manufacturability combined compatibility with roll-to-roll processing and fabrication on flexible substrates add to the merits of the perovskite PV technology [3-7]. The term "perovskite" was attributed to the crystal structure of calcium titanate $\left(\mathrm{CaTiO}_{3}\right)$, which was discovered by the German mineralogist Gustav Rose in 1839 and named in honour of the Russian mineralogist Lev Perovski [8]. The organic-inorganic hybrid halide based perovskites are widely studied in the 1990s for the application in transistor technology and light emitting diodes, due to their excellent opto-electronic properties and solution processability of these materials [9-15]. Organic-inorganic hybrid halide based perovskites are a group of materials with the general formula $\mathrm{ABX}$, where $\mathrm{A}$ is an organic cation $\left(\mathrm{CH}_{3} \mathrm{NH}_{3}{ }^{+}\right.$or $\left.\mathrm{NH}_{2} \mathrm{CH}_{3} \mathrm{NH}_{2}{ }^{+}\right)$, $\mathrm{B}$ is a divalent cation $\left(\mathrm{Pb}^{2+}\right.$ or $\left.\mathrm{Sn}^{2+}\right)$ and $\mathrm{X}$ is a monovalent halide anion $\left(\mathrm{I}^{-}, \mathrm{Br}^{-}\right.$, or $\left.\mathrm{Cl}^{-}\right)$[16-18].

Organic-inorganic hybrid halide based perovskites was first used in photovoltaics as a sensitizer replacing the dye pigment in Dye sensitized solar cells (DSSCs), which reported a 3.8\% PCE in 2009 [19]. The devices employed liquid electrolyte as hole transporting layer (HTL), therefore gained little attention due to low efficiency and poor stability. Later, the liquid electrolyte was replaced by solid-state HTL (Spiro-OMeTAD), which resulted in a solid-state device with relatively high efficiency, $\sim 9 \%$, in 2012. This breakthrough led to the so-called "perovskite fever" [20] attracting much research 
interest in the following years, eventually increasing the efficiency to a record 22.1\% [21] in early 2016. The trend in increase of performance efficiency of perovskite solar cells along with the associated timeline is shown in Figure 1 and the corresponding device details are depicted in Table 1.

24

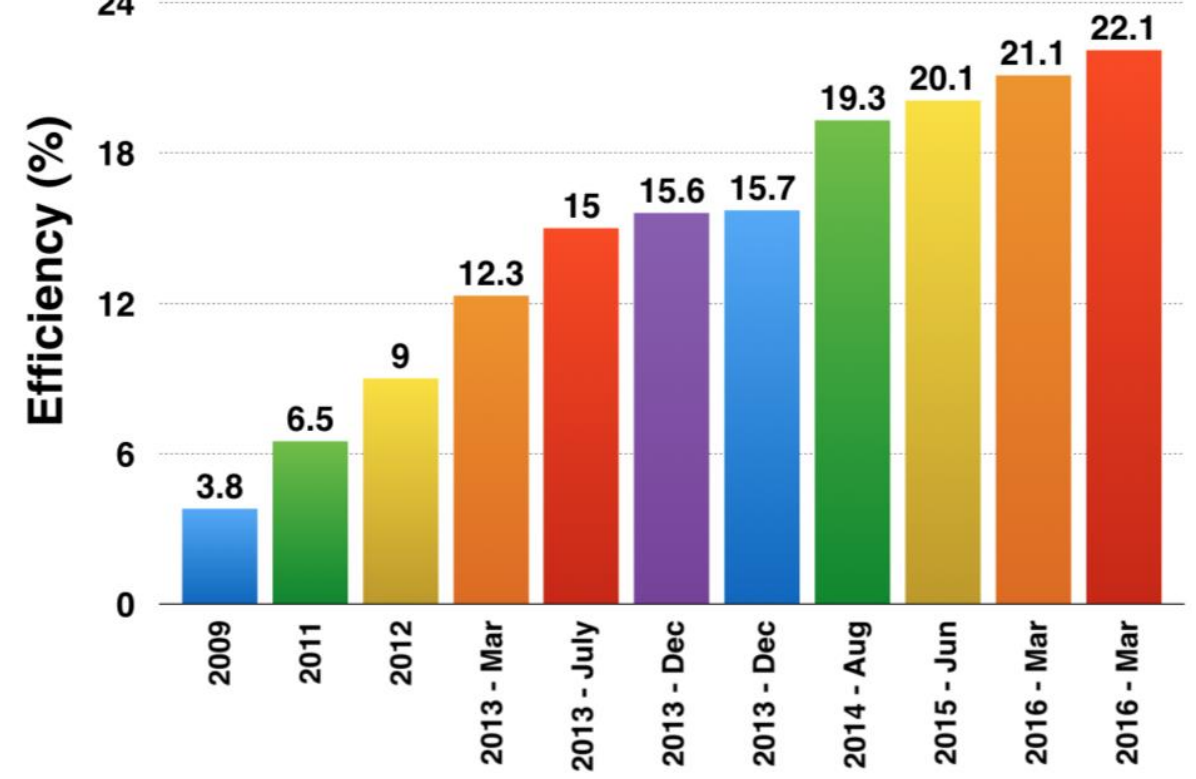

Figure 1. Efficiency trends of perovskite solar cells and its associated timeline. References are provided in Table 1.

Table 1. Development trend in perovskite solar cells with details of device structure.

\begin{tabular}{|c|c|c|c|}
\hline Year & Device Structure & PCE (\%) & Reference \\
\hline 2009 & $\mathrm{FTO} / \mathrm{bl}-\mathrm{TiO}_{2} / \mathrm{mp}-\mathrm{TiO}_{2} / \mathrm{CH}_{3} \mathrm{NH}_{3} \mathrm{PbI}_{3} /$ Redox Liquid electrolyte $/ \mathrm{Pt}$ & 3.8 & [19] \\
\hline 2011 & $\mathrm{FTO} / \mathrm{bl}-\mathrm{TiO}_{2} / \mathrm{mp}-\mathrm{TiO}_{2} / \mathrm{CH}_{3} \mathrm{NH}_{3} \mathrm{PbI}_{3} /$ Redox Liquid electrolyte $/ \mathrm{Pt}$ & 6.5 & [22] \\
\hline 2012 & $\mathrm{FTO} / \mathrm{bl}-\mathrm{TiO}_{2} / \mathrm{mp}-\mathrm{TiO}_{2} / \mathrm{CH}_{3} \mathrm{NH}_{3} \mathrm{PbI}_{3} /$ Spiro-OMeTAD $/ \mathrm{Au}$ & 9 & [23] \\
\hline March 2013 & $\mathrm{FTO} / \mathrm{bl}-\mathrm{TiO}_{2} / \mathrm{mp}-\mathrm{Al}_{2} \mathrm{O}_{3} / \mathrm{CH}_{3} \mathrm{NH}_{3} \mathrm{PbI}_{3-\mathrm{x}} \mathrm{Cl}_{\mathrm{x}} /$ Spiro-OMeTAD $/ \mathrm{Ag}$ & 12.3 & [24] \\
\hline July 2013 & $\mathrm{FTO} / \mathrm{bl}-\mathrm{TiO}_{2} / \mathrm{mp}-\mathrm{TiO}_{2} / \mathrm{CH}_{3} \mathrm{NH}_{3} \mathrm{PbI}_{3} /$ Spiro-OMeTAD $/ \mathrm{Au}$ & 15 & [25] \\
\hline 2013 & FTO/Graphene- $\mathrm{TiO}_{2} / \mathrm{mp}-\mathrm{Al}_{2} \mathrm{O}_{3} / \mathrm{CH}_{3} \mathrm{NH}_{3} \mathrm{PbI}_{3-\mathrm{x}} \mathrm{Cl}_{\mathrm{x}} /$ Spiro-OMeTAD $/ \mathrm{Au}$ & 15.6 & [26] \\
\hline December 2013 & $\mathrm{ITO} / \mathrm{np}-\mathrm{ZnO} / \mathrm{CH}_{3} \mathrm{NH}_{3} \mathrm{PbI}_{3} /$ Spiro-OMeTAD $/ \mathrm{Ag}$ & 15.7 & [27] \\
\hline August 2014 & ITO-PEIE $/ \mathrm{Y}-\mathrm{TiO}_{2} / \mathrm{CH}_{3} \mathrm{NH}_{3} \mathrm{PbI}_{3-x} \mathrm{Cl}_{x} /$ Spiro-OMeTAD $/ \mathrm{Au}$ & 19.3 & [28] \\
\hline June 2015 & $\mathrm{FTO} / \mathrm{bl}-\mathrm{TiO}_{2} / \mathrm{mp}-\mathrm{TiO}_{2} /\left(\mathrm{FAPbI}_{3}\right)_{1-x}\left(\mathrm{MAPbBr}_{3}\right)_{x} / \mathrm{PTAA} / \mathrm{Au}$ & 20.1 & [29] \\
\hline March 2016 & $\mathrm{FTO} / \mathrm{bl}-\mathrm{TiO}_{2} / \mathrm{mp}-\mathrm{TiO}_{2} / \mathrm{Cs}_{x}\left(\mathrm{MA}_{017} \mathrm{FA}_{083}\right)_{(1-\gamma)} \mathrm{Pb}\left(\mathrm{I}_{083} \mathrm{Br}_{017}\right)_{3} /$ Spiro-OMeTAD $/ \mathrm{Au}$ & 21.1 & [30] \\
\hline March 2016 & N/A & 22.1 & [21] \\
\hline
\end{tabular}

The stride of progress has been extraordinary and unprecedented in PV history and can be ascribed to numerous factors related to inexpensive fabrication costs, ease of processing, and the excellent electronic and optical properties of the perovskite materials. Moreover, the superior performance of the PSCs is reflected in their high open circuit voltage (Voc). The solar cell device efficiency ( $\eta$ ) is generally defined as $\eta=$ Jsc (short circuit current density) $\times$ Voc (open circuit voltage) $\times$ FF (fill factor). According to detailed balance theory, [31] the maximum open circuit voltage $\left(\mathrm{V}_{\mathrm{oc}-\mathrm{max}}\right)$ of a semiconductor absorber is approximately its bandgap energy $\left(E_{g}\right)$ subtracted/reduced by $0.25 \mathrm{eV}$ and the ratio of $\mathrm{V}_{\mathrm{oc}-\mathrm{max}} / \mathrm{E}_{\mathrm{g}}$ indicates the efficacy of the semiconductor material as a solar cell absorber. In line with this, the maximum theoretical limit (SQ-limit) calculated for the perovskite solar cells employing $\mathrm{CH}_{3} \mathrm{NH}_{3} \mathrm{PbI}_{3-\mathrm{x}} \mathrm{Cl}_{\mathrm{x}}$ absorber $\left(E_{\mathrm{g}} \sim 1.55 \mathrm{eV}\right)$ is as follows: Jsc (SQ-limit) is $27.20\left(\mathrm{~mA} / \mathrm{cm}^{2}\right)$, $\mathrm{Voc}_{\text {(SQ-limit) }}$ is $1.28 \mathrm{~V}, \mathrm{FF}_{\text {(SQ-limit) }}$ is 90.2 and $\mathrm{PCE}_{(\mathrm{SQ} \text {-limit) }}$ is $31.4 \%$ [32]. It clearly indicates that perovskite solar cells have immense potential for further development and the progress is promising [1,33-36]. 


\section{Crystal Structure}

The crystal structure of perovskites $\left(\mathrm{ABX}_{3}\right)$, typically consists of a unit cell with five atoms in a cubic structure ( $\alpha$ phase), in which the cation $A$ has twelve nearest neighbouring anions $X$ and the cation $B$ has six as shown in Figure 2a. Under ideal conditions, in order to maintain high-symmetry cubic structure, the tolerance factor $\mathrm{t}$ should be close to 1 . The tolerance factor $t$ is expressed as a function of ionic radii of $A, B$ and $X$ site ions, which is written as

$$
t=\frac{\left(R_{A}+R_{X}\right)}{\left\{\sqrt{2}\left(R_{B}+R_{X}\right)\right\}}
$$

where $R_{\mathrm{A}}, R_{\mathrm{B}}$, and $R_{\mathrm{X}}$ are the ionic radii of the corresponding ions. Larger the deviation from the ideal value $t$, the crystal structure will be distorted and the symmetry would be lowered. Therefore, in order to satisfy the ideal tolerance factor $(t \approx 1)$, the A-site ion must be much larger than the B-site ion. In the case of halide perovskites, in general, large $\mathrm{Pb}$ or $\mathrm{Sn}$ atom occupies the $\mathrm{B}$ site; hence the cation at A-site must be extremely large. At finite temperature, cubic structure may exist when $t$ lies between 0.89 and 1 , and smaller $t$ (i.e., $t<0.89$ ) could result in lower-symmetry tetragonal ( $\beta$ phase) or orthorhombic ( $\gamma$ phase) crystal structures. On the other hand, larger $\mathrm{t}$ (i.e., $\mathrm{t}>1)$, could undermine the three-dimensional (3D) B-X network, leading to a two-dimensional (2D) layer structure. It is noteworthy to mention that the DFT calculations computed at zero temperature have revealed that the orthorhombic ( $\gamma$ phase) is the most stable and the cubic ( $\alpha$ phase) is the most unstable structure, since it is very difficult to satisfy the ideal condition $t=1$. However, transitions between those crystal structures often occur in most perovskites at finite temperature [37-39]. The tolerance factors of some of the notable hybrid perovskite materials are shown in Figure 2c.

(a)

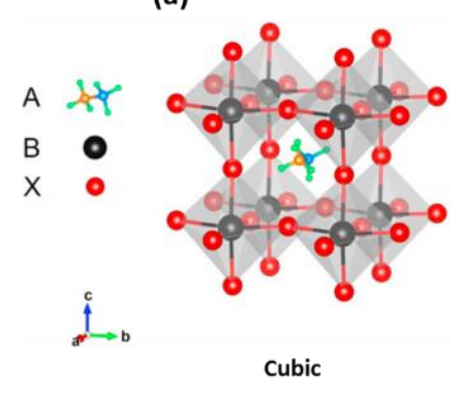

(b)

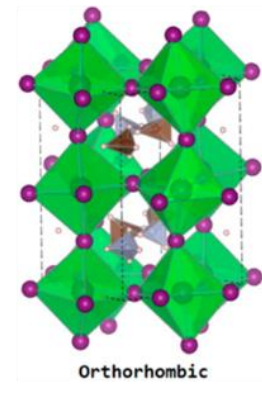

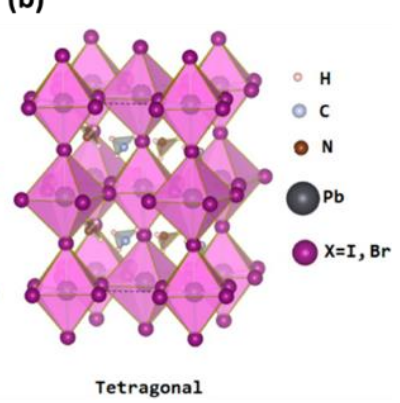

(c)

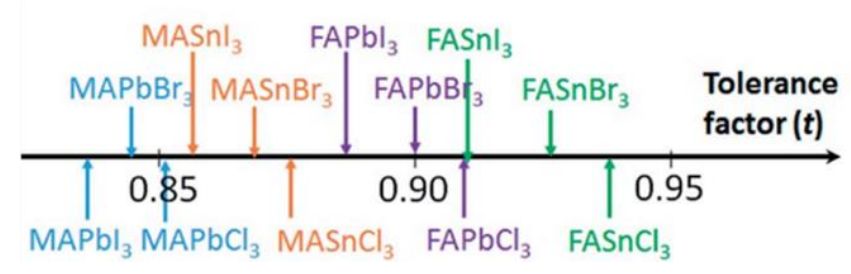

Figure 2. (a) Crystal structure of cubic ( $\alpha$ phase); (b) crystal structure of the tetragonal crystal system $(\beta)$ phase and orthorhombic $(\gamma)$ phase of $\mathrm{MAPbX}_{3}$; and (c) the tolerance factor for different perovskite material systems, $\mathrm{t}=1$ is ideal. Image: (a) copyright [40]; (b) copyright [41]; and (c) copyright [42].

The perovskite material $\left(\mathrm{CH}_{3} \mathrm{NH}_{3} \mathrm{PbI}_{3}\right)$ undergoes reversible phase transition as a function of temperature [43]. At low temperature of about $100 \mathrm{~K}$, a stabilized orthorhombic $(\gamma)$ phase exists and the phase transition between the tetragonal $(\beta)$ phase and orthorhombic $(\gamma)$ phase occurs at around $160 \mathrm{~K}$. The crystal structure for three phases is shown in Figure 2a-c. The tetragonal-cubic phase transition partially influences the thermal stability issue for $\mathrm{MAPbI}_{3}$ based PSCs [44]. In the case of formamidinium iodide $\left(\mathrm{HC}\left(\mathrm{NH}_{2}\right)_{2} \mathrm{PbI}_{3}\right)$ based perovskites, a similar phase transition occurs at higher 
temperature, hence it is relatively stable compared to $\mathrm{MAPbI}_{3}$. A recent report revealed light soaking could also induce reversible structure transformation in halide perovskite materials [45].

\section{Electronic Structure of Perovskites}

The electronic structure of hybrid perovskites especially near the band edge is predominantly dictated by the $\mathrm{BX}_{6}$ (octahedra) building blocks. For instance, in the case of $\left[\mathrm{PbI}_{6}\right]^{4-}$ units in particular, the valence band (or highest occupied molecular orbital, HOMO) is determined by the $\mathrm{Pb} 6 \mathrm{~s}-\mathrm{I} 5 \mathrm{p}$ $\sigma$-antibonding orbital. Similarly, the conduction band (or lowest unoccupied molecular orbital, LUMO) is determined by the $\mathrm{Pb} 6 \mathrm{p}-\mathrm{I} 5 \mathrm{p} \pi$-antibonding and $\mathrm{Pb} 6 \mathrm{p}-\mathrm{I} 5 \mathrm{~s}$-antibonding orbitals [46-51]. The unusual electronic properties of hybrid perovskites is mainly ascribed to the lone pair of s electrons in $\mathrm{Pb}$ cation, i.e., unlike most cations whose outer s orbitals are empty, $\mathrm{Pb}$ has an occupied $6 \mathrm{~s}$ orbital, which lies below the top of the valence bands [52,53]. The valence band maximum (VBM) has strong $\mathrm{Pb}$ s and I $\mathrm{p}$ antibonding character, whereas the conduction band minimum (CBM) is mostly contributed from the $\mathrm{Pb} \mathrm{p}$ state, which attributes to the unique dual nature (ionic and covalent characteristics) of electronic structures in halide perovskites. Figure 3 (top) shows the atomic structure of perovskite $\left(\mathrm{ABX}_{3}\right)$ and the contribution of each of its atoms/ions towards the electronic structure of the perovskite material. In the hybrid perovskite structure of $\mathrm{MAPbI}_{3}$, the iodine ions at the $\mathrm{X}$-site forms the valence band and the lead (anion) at the B-site forms the conduction band, while organic cation at the A-site remains electronically inactive but contributes to the structural stability and tolerance factor of the perovskite structure.

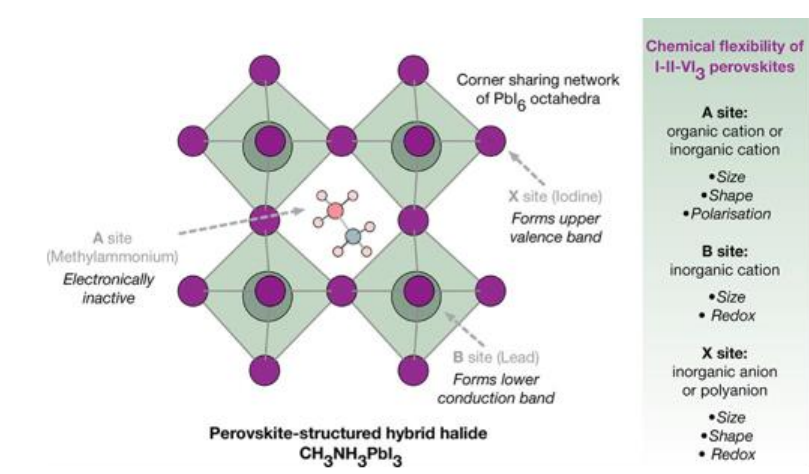

(a)

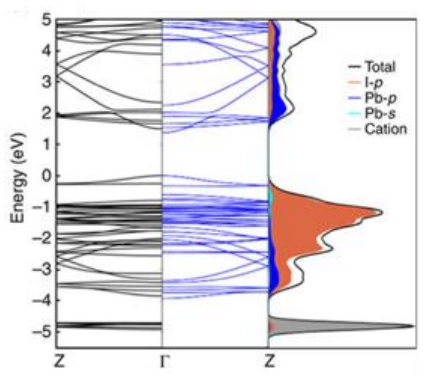

(b)

Perovskite halide

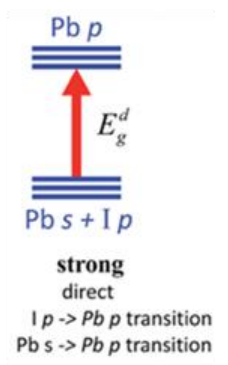

(c)

1st generation

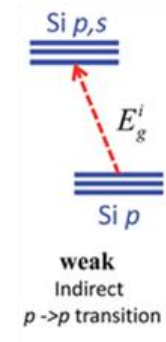

(d)

2nd generation

Gas + As $s$

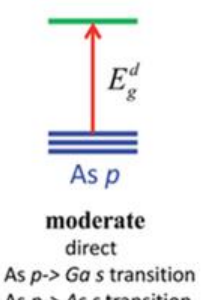

Figure 3. Top: Schematic of the perovskite crystal structure with respect to the A, B and X lattice sites and their contribution to the electronic structure-copyright [54]; Bottom: (a) Contributions of MA, Pb, and I on the density of state of $\mathrm{MAPbI}_{3}$ perovskite (copyright [55]). The schematic optical absorption of: (b) halide perovskite solar cell absorber; (c) first-generation (Si); and (d) second-generation (GaAs as example) (copyright [32]).

The contributions of $\mathrm{MA}, \mathrm{Pb}$, and I on the density of state of $\mathrm{MAPbI}_{3}$ perovskite are shown in Figure 3a (bottom). It can be clearly seen that the grey coloured distribution pertaining to the A cation lies well below the valence band maximum (VBM), therefore does not contribute to the bandgap 
electronically. The uniqueness of the electronic structure of the halide perovskites is also shown in Figure $3 \mathrm{~b}-\mathrm{d}$, comparing with 1st generation ( $\mathrm{Si}$ solar cells) and 2nd generation (GaAs as an example). In conventional semiconductors like GaAs, the CBM is predominantly determined by s orbital and the VBM is primarily determined by $\mathrm{p}$ orbital $[32,56]$. In contrast, the halide perovskites exhibit inverted electronic band structure (see Figure $3 b, d)$ ). The halide perovskites have strong optical absorption than that of the first-generation and second-generation semiconductors shown above-mainly due to the electronic band structure. The first-generation absorber (silicon) is an indirect bandgap material and its transition probability between conduction and valence band edges is about two orders of magnitude lower than that of the direct bandgap semiconductors (halide perovskite or GaAs), therefore, making its absorber layer to be two orders of magnitude thicker and consequently increasing the material cost.

Though $\mathrm{GaAs}$ and $\mathrm{CH}_{3} \mathrm{NH}_{3} \mathrm{PbI}_{3}$ have direct bandgap, their electronic structures are very different. Dispersive $s$ band (delocalized s orbitals) dictates the lower part of the $\mathrm{CB}$ of $\mathrm{GaAs}$, whereas the degenerate $\mathrm{Pb}$ p bands dictate the lower part of the $\mathrm{CB}$ of the halide perovskite $\left(\mathrm{CH}_{3} \mathrm{NH}_{3} \mathrm{PbI}_{3}\right)$. The atomic $\mathrm{p}$ orbitals exhibit relatively less dispersion than those of $\mathrm{s}$ orbitals. Hence, the density of states (DOS) pertaining to the conduction band minimum (CBM) is significantly higher than that of GaAs (Figure 4a) and consequently leading to higher Joint density of states (JDOS) (Figure 4b). Moreover, the energy level transition between $\mathrm{VB}$ and $\mathrm{CB}$ for $\mathrm{CH}_{3} \mathrm{NH}_{3} \mathrm{PbI}_{3}$ is contributed from mixed $(\mathrm{Pb} \mathrm{s}, \mathrm{I} \mathrm{p})$ to $\mathrm{Pb}$ p orbitals (see Figure $3 b$ ). Here, the intra-atomic transition probability between the $\mathrm{Pb} \mathrm{s}$ to $\mathrm{Pb} \mathrm{p}$ is relatively high in halide perovskites when compared to that of $\mathrm{GaAs}$ and it is the reason behind stronger optical absorption of perovskites than GaAs as shown in Figure 4c. It is worthy mentioning that optical absorption coefficient of $\mathrm{CH}_{3} \mathrm{NH}_{3} \mathrm{PbI}_{3}$ is up to 1 order of magnitude higher than that of GaAs within the visible light range and hence relatively lower thickness is needed for absorber materials to attain maximum efficiency as shown in Figure 4d [32].
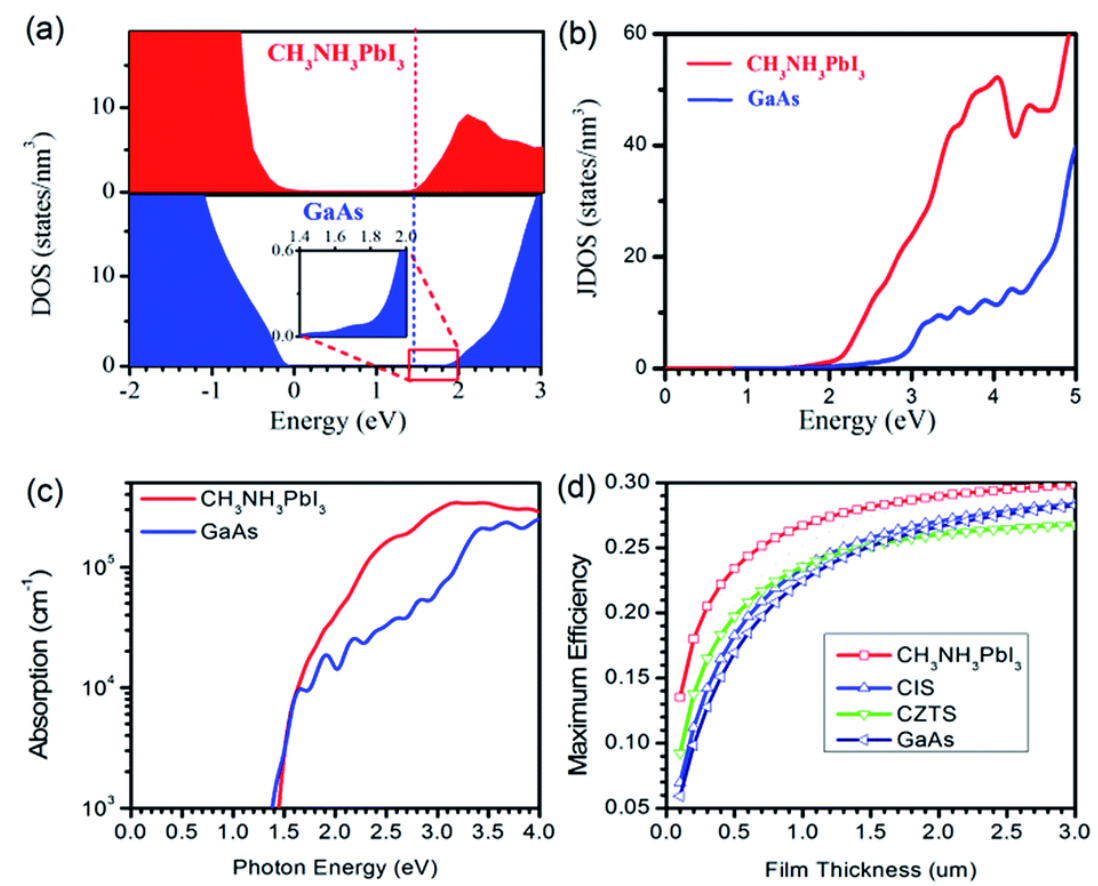

Figure 4. (a) Density of states (DOS) of $\mathrm{CH}_{3} \mathrm{NH}_{3} \mathrm{PbI}_{3}$ and GaAs. The VBMs are referred to as zero energy and CBMs are marked as dashed lines; (b) the Joint density of states (JDOS) of $\mathrm{CH}_{3} \mathrm{NH}_{3} \mathrm{PbI}_{3}$ and GaAs; (c) the optical absorptions of $\mathrm{CH}_{3} \mathrm{NH}_{3} \mathrm{PbI}_{3}$, and $\mathrm{GaAs}$; and (d) calculated maximum efficiencies of halide perovskites, CIS, CZTS, and GaAs as a function of film thickness (copyright [32]).

Another important unique characteristic of halide perovskites is that the grain boundaries (GB) are electrically benign. Unlike in conventional polycrystalline light absorbers, where GBs are 
usually detrimental to solar cell performance, the effect of GBs in halide perovskites are electrically invisible [57] and reports have even shown that it is quite favourable for better device performance [58]. The electrically benign nature of GBs in halide perovskites is primarily correlated to their electronic structures. The valence band maximum (VBM) in halide perovskites is energetically much higher than I $5 p$ due to strong coupling between $\mathrm{Pb} 6 \mathrm{~s}$ and I 5p, which consequently increases the level of VBM. Higher VBM implicates lower defect levels or shallow defect states, therefore charge carrier recombination propagated by the defect states are much lower in halide perovskites [32]. The extremely efficient charge transport and charge collection characteristics in perovskite solar cells are also attributed to the unique electronic structure of the halide perovskites as discussed earlier. Ambipolar carrier diffusion combined with long and balanced charge carrier diffusion lengths can be added to the merits of the unique electronic structure $[32,59,60]$.

One of the remarkable aspects of halide perovskites is their capability to produce high-quality semiconductor films from solution processing methods. For $\mathrm{CH}_{3} \mathrm{NH}_{3} \mathrm{PbI}_{3}$ thin films, four magnitude of increase in mobility ( 8 to $35 \mathrm{~cm}^{2} \cdot \mathrm{V}^{-1} \cdot \mathrm{s}^{-1}$ ) has been observed by Time-resolved terahertz spectroscopy (TRTS) which can be attributed to better solution processing or deposition techniques [61,62]. Similarly, $\mathrm{CH}_{3} \mathrm{NH}_{3} \mathrm{PbI}_{3}$ thin films fabricated from $\mathrm{PbI}_{2}$ or $\mathrm{PbAc}$ precursor resulted in different diffusion length $\left(L_{D}=200 \mathrm{~nm}\right.$ vs. $600 \mathrm{~nm}$, respectively) [63]. The variation of charge carrier mobility and diffusion length as a function of crystal structure of perovskite is shown in Figure 5 [61]. The variation of electronic properties depending on the measurement methods and perovskite material composition are listed in Table 2. The electronic properties relatively decrease as the perovskite phase transitions' into the cubic structure at room temperature.

(a)

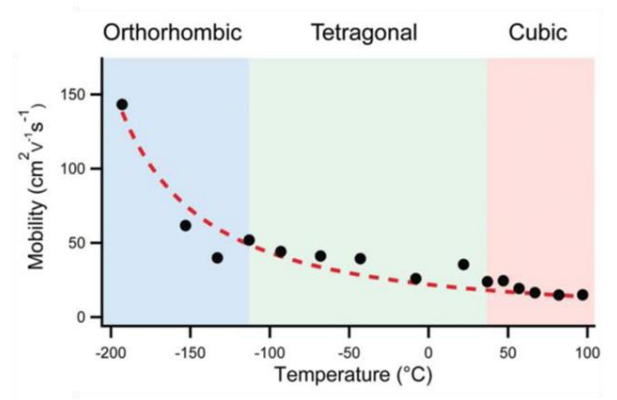

(b)

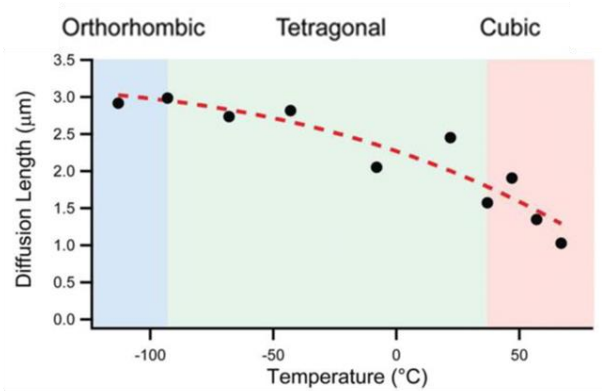

Figure 5. (a) Temperature dependence of the mobility; and (b) diffusion length as predicted for band-like transport in different phases (orthorhombic, tetragonal and cubic) of $\mathrm{MAPbI}_{3}$ perovskite. Copyright [61].

Table 2. Diffusion length (LD) and mobility $(\mu)$ measured for notable hybrid perovskites thin films.

\begin{tabular}{|c|c|c|c|c|c|}
\hline $\begin{array}{c}\text { Compound } \\
\text { (Perovskite Thin Films) }\end{array}$ & $\begin{array}{l}\text { Measurement } \\
\text { Technique }\end{array}$ & $\begin{array}{l}\text { Mobility }(\mu) \\
\left(\mathrm{cm}^{2} \cdot \mathrm{V}^{-1} \cdot \mathrm{s}^{-1}\right)\end{array}$ & $\begin{array}{c}\text { Diffusion Length, } \\
L_{D}(\mu \mathrm{m})\end{array}$ & $\begin{array}{c}\text { Charge lifetime, } \\
\tau \text { (ns) }\end{array}$ & Reference \\
\hline \multirow{3}{*}{$\mathrm{CH}_{3} \mathrm{NH}_{3} \mathrm{PbI}_{3}$} & PLQ & 0.66 & 0.13 & 9.6 & [64] \\
\hline & PLQ & 1.4 & 0.13 & 4.5 & [65] \\
\hline & TRTS & 8.2 & 1.2 & 67 & {$[62]$} \\
\hline \multirow{2}{*}{$\mathrm{CH}_{3} \mathrm{NH}_{3} \mathrm{PbI}_{3-\mathrm{x}} \mathrm{Cl}_{\mathrm{x}}$} & PLQ & 1.6 & 1.07 & 273 & [64] \\
\hline & TRTS & 11.6 & 2.4 & 200 & {$[62]$} \\
\hline $\mathrm{CH}_{3} \mathrm{NH}_{3} \mathrm{PbBr}_{3}$ & PLQ & 8.9 & 1.06 & 51 & {$[66]$} \\
\hline \multirow{2}{*}{$\mathrm{CH}\left(\mathrm{NH}_{2}\right)_{2} \mathrm{PbI}_{3}$} & PLQ & 0.16 & 0.18 & 75 & [67] \\
\hline & TRTS & 27 & 3.1 & 140 & {$[68]$} \\
\hline $\mathrm{CH}\left(\mathrm{NH}_{2}\right)_{2} \mathrm{PbBr}_{3}$ & TRTS & 14 & 1.3 & 50 & {$[68]$} \\
\hline $\mathrm{CH}_{3} \mathrm{NH}_{3} \mathrm{SnI}_{3}$ & TRTS & 1.6 & 0.03 & 0.2 & [69] \\
\hline
\end{tabular}

Legend: PLQ, Photo Luminescence Quenching; TRTS, Time-Resolved Terahertz Spectroscopy. 
The forthcoming sections provide a brief overview of device architectures, fabrication methods and charge selective contacts employed in PSCs.

\section{Perovskite Solar Cell Device Architectures}

Perovskite solar cells evolved from the mesoscopic structure (Figure 6a) in which the halide perovskite semiconductors replaced the light harvesting dye [23,70,71]. Later, the liquid electrolyte was replaced with a solid-state hole conductor. The advent attracted much interest in the PV community, which resulted in the development of other device structures as shown in Figure $6 \mathrm{~b}-\mathrm{d}$. The planar device structure is developed in which the perovskite absorber is sandwiched between the electron (ETM) and hole transporting materials (HTM). The n-i-p is also called as normal device structure and $\mathrm{p}-\mathrm{i}-\mathrm{n}$ structure is also called as inverted device structure. Simply, depending on the position of the ETM and HTM, the device structure varies [70,72-74]. The details about the different electron and hole transporting layers are discussed in the forthcoming section.

(a) n-i-p mesoscopic

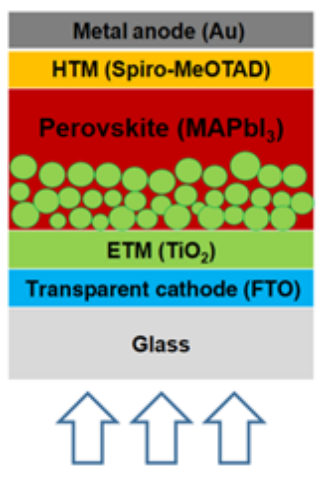

(b) $n-i-p$ planar

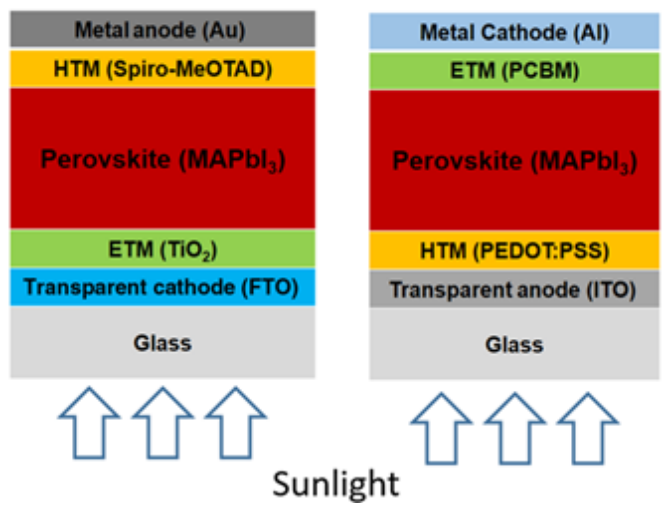

(d) p-i-n mesoscopic

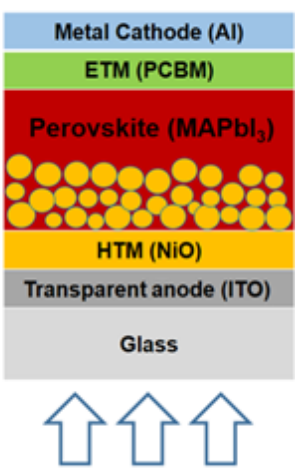

Figure 6. Schematic diagrams of perovskite solar cells in the: (a) n-i-p mesoscopic; (b) n-i-p planar; (c) p-i-n planar; and (d) p-i-n mesoscopic structures. (a,b) Normal device structure; and (c,d) inverted device structure (copyright [70]).

Recently, Silvia et al. [75] demonstrated perovskite solar cells with fullerene as electron transporting layer (ETL) which exhibited PCE $>10 \%$ in n-i-p planar device configuration. The authors incorporated an innovative fullerene-saturation approach/strategy (the perovskite processing solution is saturated with fullerene) to avoid the damage of the fullerene film through dissolution during the deposition of the perovskite layer. Another interesting finding was also demonstrated by the same research group, where the perovskite solar cells are fabricated without the electron transport layer with solution processed methylammonium lead triiodide perovskite- $C_{70}$ fullerene $\left(\mathrm{MAPbI}_{3}: \mathrm{C}_{70}\right)$ blend films on fluorine-doped tin oxide (FTO)-coated glass substrates [76]. The ETL-free devices thus fabricated exhibited PCE of $13.6 \%$ with significantly low carrier recombination when compared to conventional $\mathrm{MAPbI}_{3}$ perovskite layer. The ETL-free devices also exhibited high photostability in comparison to the conventional regular n-i-p architecture with $\mathrm{TiO}_{2}$ based ETL.

\section{Fabrication Methods}

In the "one-step" deposition or spin coating method, the perovskite precursors of appropriate stoichiometry are prepared in a common solution and are then spin coated into a thin film (Figure 7a) [77]. Power conversion efficiency of over $20 \%$ has been achieved using this single step method [28,34]. In the case of "two-step" deposition method or "sequential" deposition process, two precursor solutions are prepared. For instance, a thin film is first deposited using metal halide (e.g., $\mathrm{PbI}_{2}$ ) precursor using spin coating process (mostly) and then the film coated substrate is dipped into the second precursor solution (Figure $7 b$ ) $[78,79]$. PSCs are also fabricated using the doctor 
blade method (PCE $\sim 15 \%$ ) and slot die coating ( 12\%), which could be a versatile approach for scalability $[80,81]$. Dual source evaporation or vacuum deposition methods was also used to deposit perovskite thin films, which provided the advantage of producing pin-hole free layers with uniform thickness-resulting in PCE of $\sim 15 \%$ [82]. However, this method presents challenges for scalability and also requires relatively high energy for film fabrication. Hybrid approach of using both solution processing and vapour deposition to fabricate perovskite thin films was also developed. Here, the $\mathrm{PbI}_{2}$ precursor is first spin-coated and then the methyl ammonium iodide (MAI) is evaporated on top of the as-deposited $\mathrm{PbI}_{2}$ film and a PCE of $\sim 12 \%$ was achieved using this method [83]. Table 3 lists some of the other best perovskite solar cells (PCE > 17\%) fabricated using different deposition methods.

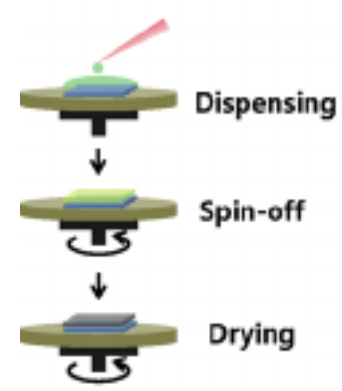

(a)

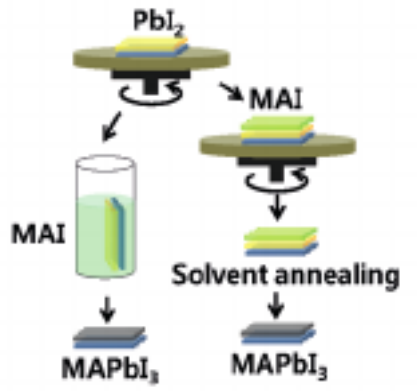

(b)

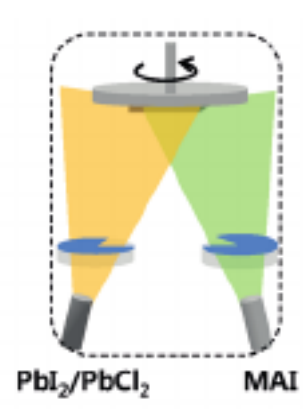

(c)

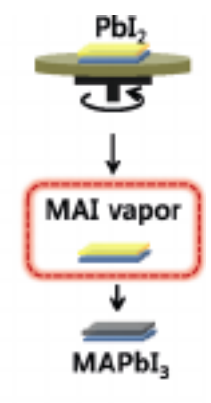

(d)

Figure 7. Representative fabrication methods for perovskite thin films: (a) one-step spin-coating method; (b) two step or sequential deposition method; (c) dual-source vapour deposition; and (d) vapour-assisted solution process (copyright [77]).

Table 3. Fabrication methods and performance of PSCs (for devices with PCE >17\%).

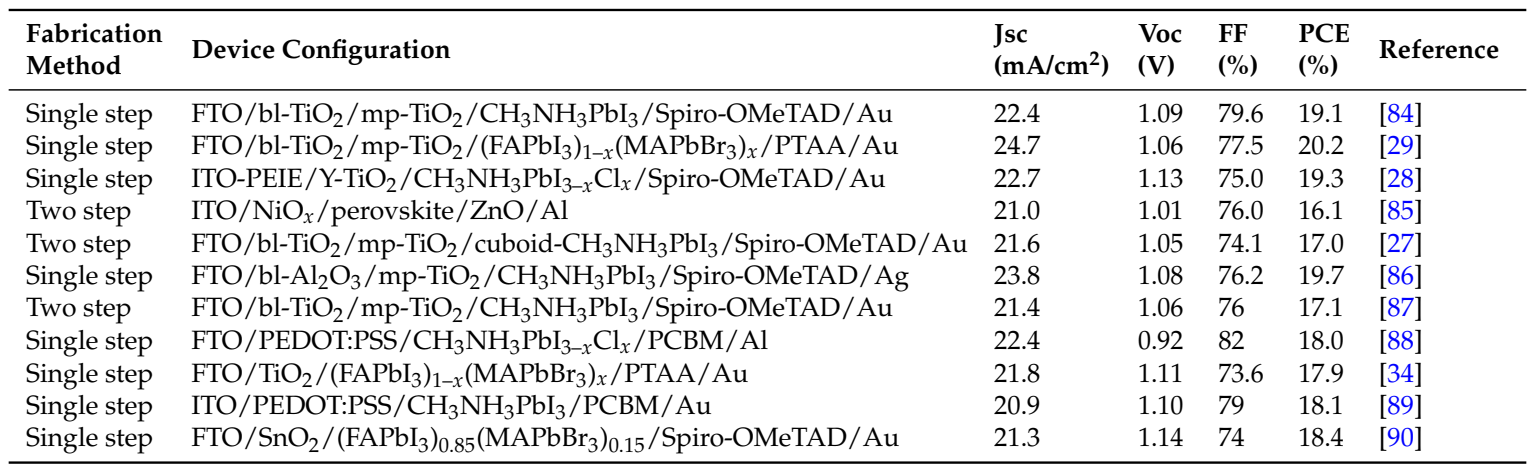

\section{Charge Selective Contacts and Interfaces}

Charge selective layers play an important role in the performance of PSCs. Electron transport layer (ETL) and hole transport layer (HTL) when placed on either side of the light absorbing perovskite layer, provides unidirectional pathway for charge carriers. For instance, the ETL layer allows electrons and acts as hole blocker and HTL vice versa. Therefore, the charge selective layers influence the charge transport or charge extraction properties and thus the charge recombination rate significantly. Moreover, interface engineering using the charge selective contacts can also passivate various physical and electronic defects that could exist in the perovskite film, which includes voids, pin holes, energetic barriers, defect states etc. For instance, incorporation of PEIE on top of ITO modifies the work function of ITO from $4.6 \mathrm{eV}$ to $4.0 \mathrm{eV}$, thereby reducing the electronic barrier at the $\mathrm{ITO} / \mathrm{TiO}_{2}$ interface in an ITO/PEIE/PCBM/Y: $\mathrm{TiO}_{2} / \mathrm{MAPbI}_{3} /$ spiro-OMeTAD/Au device [28]. Such modification has shown to improve the Jsc from 18.9 to $19.9 \mathrm{~mA} \cdot \mathrm{cm}^{-2}$ and increasing the FF from $65.25 \%$ to $73.28 \%$. Similarly, reports have shown that by incorporating an ultra-thin P3TMAHT intercalating layer in the device structure for efficient hole extraction, the average PCE was improved from $8.52 \%$ to 
$11.28 \%$ [82]. Dedicated reviews on interfacial engineering of perovskite solar cells can be found in the literature [72-74]. Some of the notable materials employed in PSC device fabrication are shown in Figure 8.

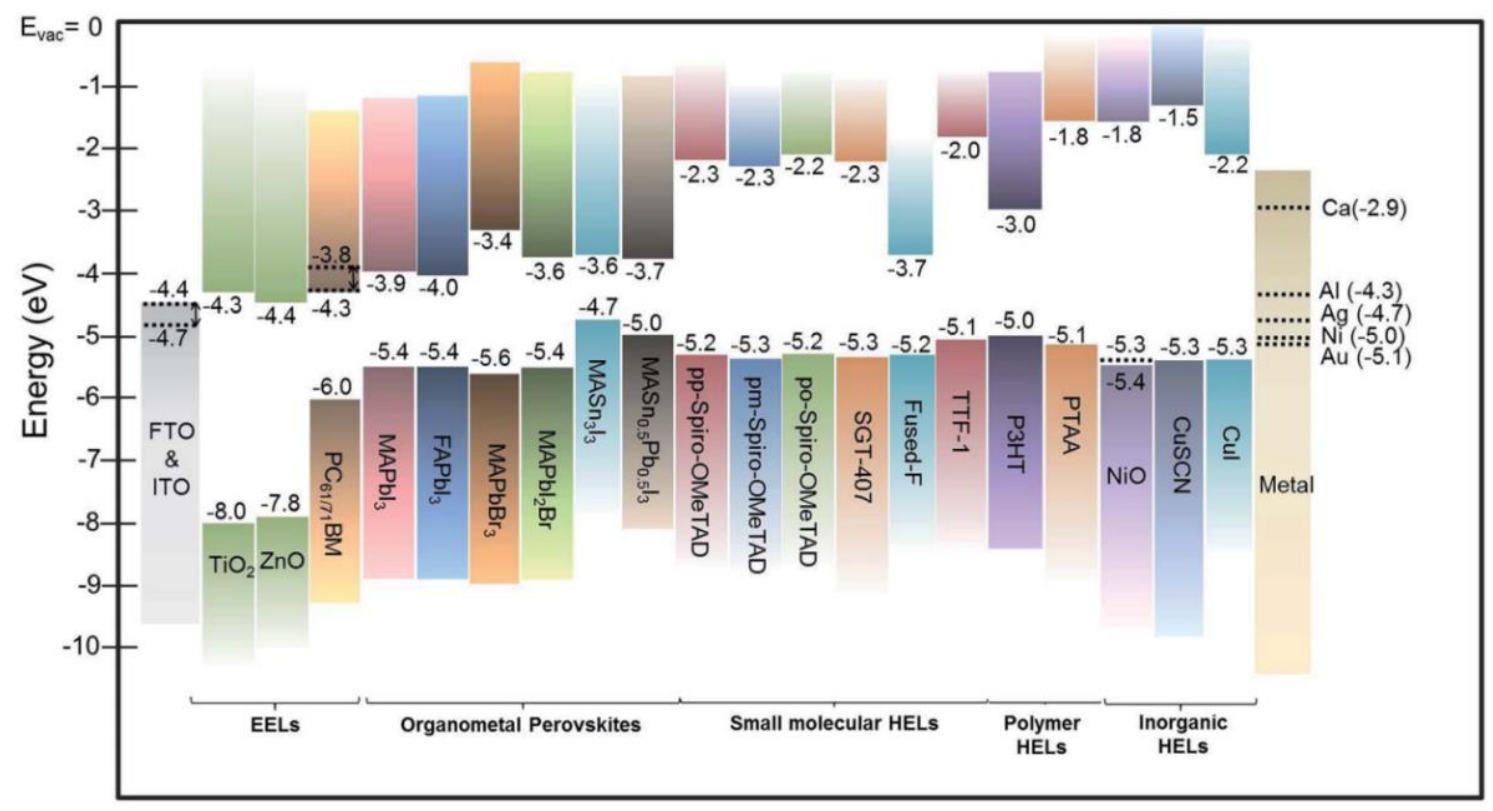

Figure 8. Schematic of energy level diagram of representative hybrid halide perovskites and charge-extraction interlayers. The dotted lines represent the WF of the materials (copyright [91]).

\section{Challenges in Perovskite Solar Cells}

As discussed earlier, perovskite solar cells have seen unprecedented development in the past few years. The advancements in terms of performance efficiency were not equally matched with the fundamental understanding of inherent electronic and physio-chemical properties, modulating the photovoltaic parameters of the devices. Hence, many challenges still remain which include hysteresis phenomenon observed during solar cell operation, improving the reproducibility of efficient devices, increasing the stability of the PSCs by making it thermal and moisture stable as well as reducing the reducing the amount of toxic ( $\mathrm{Pb}$-containing) material used in devices. Among these, the hysteresis and stability issue are found to be the most pressing issue as they serve as the bottleneck for commercialization. Further important challenges might arise from the scalability issues involved in the fabrication of perovskite solar cells. The details are discussed in the following sections.

\subsection{Hysteresis}

Hysteresis in HPSCs indicates the variations in the current-voltage response curves in which the corresponding photovoltaic parameters vary depending on the direction and rate of the scan as shown in Figure $9 \mathrm{a}, \mathrm{b}$ as an example. Reversible hysteresis was reported by numerous research groups in $\mathrm{MAPbI}_{3}$-based devices of all architectures (normal and inverted) [92-95]. The scanning direction is called as backward or reverse scan when the voltage is swept from positive (open circuit) to negative (short circuit), whereas the scan in the opposite direction is termed as forward scan [96]. Therefore, hysteresis imposes a serious problem on the accurate determination of perovskite solar cell efficiencies and long term device operational stability. Furthermore, there are increasing apprehensions over some reported efficiencies as the devices are vulnerable to current-voltage (I-V) hysteresis effects. Hence, it is very much indispensable to decipher the origin or mechanisms of the I-V hysteresis in order to minimize or eradicate this anomalous behaviour completely for reliable quantification. 

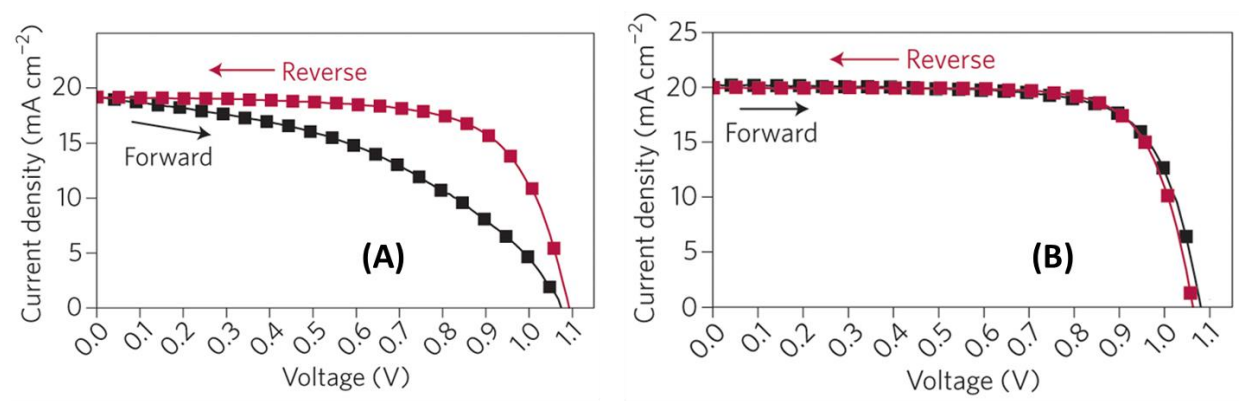

(C)
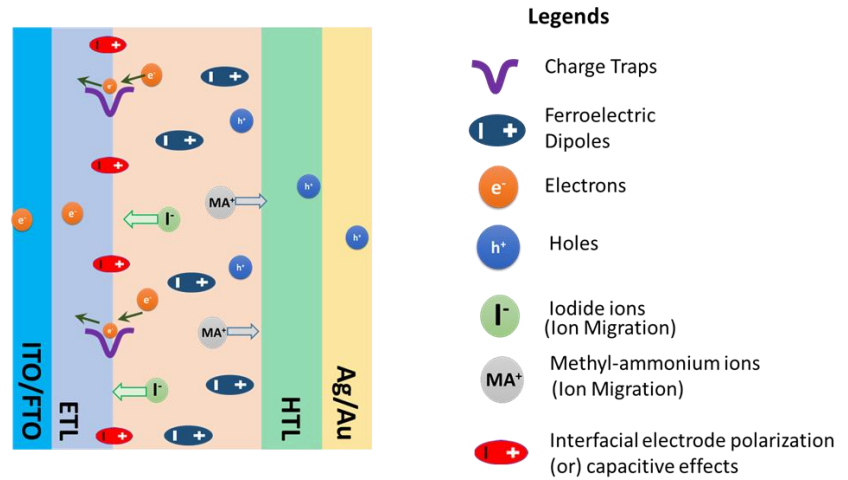

Figure 9. (A) The current-voltage (I-V) response with hysteresis; and (B) negligible hysteresis of HPSCs (copyright [96]). (C) Schematic showing the various processes (or origins) occurring in the perovskite solar cells (in normal device structure as an example) that could possibly lead to hysteresis phenomenon during I-V measurements (copyright [95]).

Although the origin of hysteretic effects is still unclear, there are numerous mechanisms that have already been proposed to explain the causes. The following mechanisms (Figure 9c) are found to govern the hysteresis phenomenon in perovskite solar cells: (i) Ferroelectric polarization [94,97,98]; (ii) Ion migration [99-101]; (iii) Charge trapping [102,103]; and (iv) capacitive effects [104]. Dedicated reviews on hysteresis phenomenon in perovskite solar cells can be found in the literature [95]. Since the perovskite solar cells are prone to hysteresis issues, extra care should be taken while measuring the I-V data for reporting of efficiencies. Addressing this issue, an article has been published recently comprising of step-by-step guidelines for proper characterization of perovskite solar cells [105]. The authors described the characterization techniques similar to the best practices and measurement standards followed in independent efficiency measurement labs like AIST, Fraunhofer ISE and NREL etc. The protocols include: (i) Masking the cell appropriately and measuring the device area accurately; (ii) Calibrating the illumination source; (iii) Determining the steady state Jsc and Voc and simultaneously monitoring its stability; (iv) Measuring the J-V curves at the forward and reverse direction at various scan rates; (v) Measuring steady-state photocurrent at several different voltages near maximum power point; $\mathrm{P}_{\max }$ (vi) Calculating the Jsc by integrating the IPCE data; and (vii) performing statistical analysis across multiple measurement sample sets [105].

\subsection{Stability}

Another major challenge in perovskite PV technology is the degradation or lifetime of perovskite solar cells. The performance efficiency of PSCs decreases over a period of time as the degradation occurs. In order to pass the standard International Electrotechnical Commission damp heat test $\left(85^{\circ} \mathrm{C}, 85 \%\right.$ relative humidity), photovoltaic modules is expected to undergo less than $10 \%$ efficiency loss in $1000 \mathrm{~h}$ (just over 40 days) [106,107]. Given this metric for stability requirement, the perovskite solar cells are far from satisfying this condition till date. The degradation can occur when the devices are exposed to moisture, continuous illumination, thermal-stress and oxygen [40,107-113]. The basic degradation mechanism in PSCs is the breakdown of perovskite material under moisture or heat 
stress, which results in the segregation of MAPbI3 into its constituents $\mathrm{PbI}_{2}$ and MAI [114-116]. It is summarized as: $\mathrm{CH}_{3} \mathrm{NH}_{3} \mathrm{PbI}_{3} \rightarrow \mathrm{PbI}_{2}+\mathrm{CH}_{3} \mathrm{NH}_{2} \uparrow+\mathrm{HI} \uparrow$

The perovskite $\mathrm{CH}_{3} \mathrm{NH}_{3} \mathrm{PbI}_{3}$ thin films are found to undergo decomposition under thermal stress at a temperature between $\sim 100{ }^{\circ} \mathrm{C}$ [117] and $140{ }^{\circ} \mathrm{C}$ [118]; the decomposition rate increases further as the temperature is increased [119]. Figure 10a shows the possible pathways of degradation of perovskite via moisture ingression and iodide ion migration. Improvement in device stability by the incorporation of phosphonic acid ammonium additive in the perovskite structure of $\mathrm{CH}_{3} \mathrm{NH}_{3} \mathrm{PbI}_{3}$ is reported to increase the moisture resistance of the material by acting as a crosslink between neighbouring grains [120] is shown in Figure 10b, where the stability is remarkably improved relative to the pristine control $\left(\mathrm{MAPbI}_{3}\right)$ devices. Figure 10c shows the device structure of carbon based encapsulation in triple-layer PSCs which exhibited superior device stability [121].The carbon layer protects the device from moisture ingression and the scaffolding provides protection against thermal stress [121,122]. Typically, testing under encapsulation denotes sealing the device completely in a glass or by sealing the device using thermosetting epoxy glue $[123,124]$. Such kind of encapsulation protects the device or adjacent films from oxygen and moisture ingression, thereby extending the long term stability of the devices. Figure 10d shows the stability enhancement in PSCs via triple (or multiple) cation mixtures with two different compositions - $\mathrm{Cs}_{5} \mathrm{M}$ and $\mathrm{Cs}_{0} \mathrm{M}$, where $\mathrm{Cs}_{\mathrm{x}}$ represents the percentage of Caesium ( $5 \%$ and $0 \%)$ respectively and $\mathrm{M}$ stands for "mixed perovskite". Addition of small amount of Cs to MA/FA mixtures suppresses the device degradation occurring due to phase separation and also improves the device performance significantly [30].

(a)

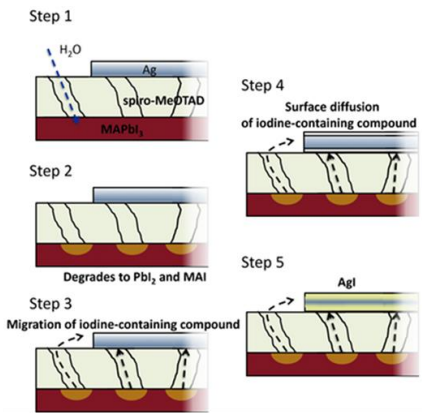

(c)

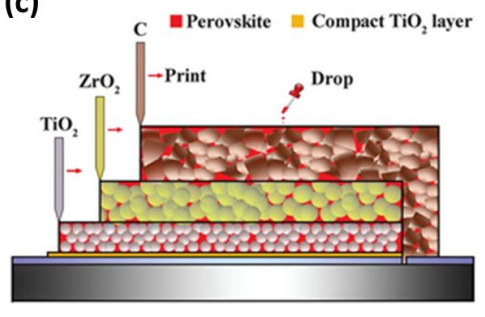

(b)

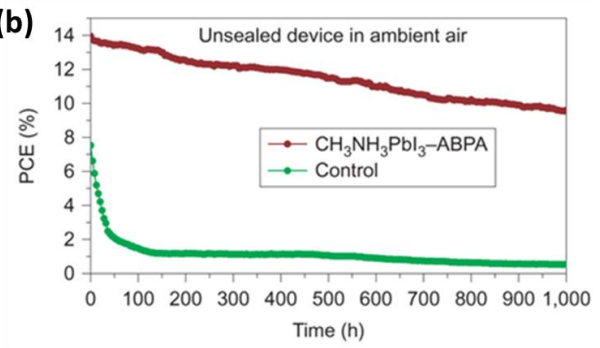

(d)

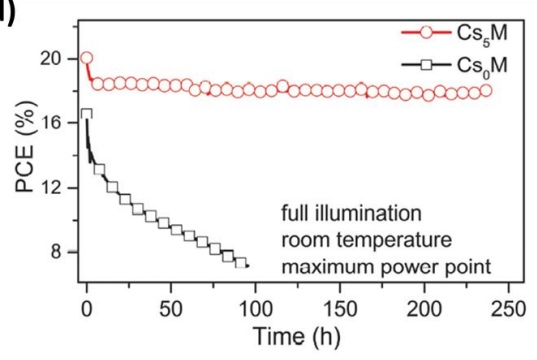

Figure 10. (a) Schematic illustration of a proposed mechanism of silver iodide (AgI) formation: (1) Moisture $\left(\mathrm{H}_{2} \mathrm{O}\right)$ in air enters through pinholes into the spiro-MeOTAD (HTL) layer. (2) Decomposition of perovskite $\left(\mathrm{MAPbI}_{3}\right)$ leads to an iodine containing volatile compound (MAI and/or HI. (3) Migration of the iodine containing volatile compound from the $\mathrm{MAPbI}_{3}$ layer corroding the electrode from both the top and bottom surface of silver (Ag) layer. (4) Surface diffusion of the iodine containing volatile compound. (5) Silver iodide (AgI) formation. Copyright [125]. (b) Variation of PCE as a function of time of unsealed perovskite solar cells stored in ambient air at $\sim 55 \%$ humidity in the dark. Copyright [120]. (c) Schematic cross section of the triple-layer perovskite-based fully printable mesoscopic solar cell. Copyright [121] (d) Aging for 250 hours of a high performance $\mathrm{Cs}_{5} \mathrm{M}$ and $\mathrm{Cs}_{0} \mathrm{M}$ devices in a nitrogen atmosphere held at room temperature under constant illumination and maximum power point tracking. Copyright [30]. Table 4 shows some of the highly stable perovskite solar cells and their lifetime reported in literature. 
Table 4. List of some of the stable perovskite solar cells and lifetime values in literature.

\begin{tabular}{|c|c|c|c|c|}
\hline Device Structure & $\begin{array}{l}\text { Efficiency } \\
(\%)\end{array}$ & $\begin{array}{l}\text { Expt. Conditions } \\
\text { (Light, Moisture, Temperature) }\end{array}$ & Stability & Reference \\
\hline $\begin{array}{l}\mathrm{FTO} / \mathrm{TiO}_{2} / \mathrm{Al}_{2} \mathrm{O}_{3}+ \\
\mathrm{MAPbI}_{3-x} \mathrm{Cl}_{x} / \text { Li-spiro } / \mathrm{Ag}\end{array}$ & 12.6 & $80^{\circ} \mathrm{C}$, air & $48 \mathrm{~h}$ & [126] \\
\hline $\mathrm{FTO} / \mathrm{c}-\mathrm{TiO}_{2} / \mathrm{MAPbI}_{3-x} \mathrm{Cl}_{x} /$ spiro $/ \mathrm{Au}$ & 9.2 & Dark, air & 3 months & [127] \\
\hline $\mathrm{FTO} / \mathrm{TiO}_{2} / \mathrm{Al}_{2} \mathrm{O}_{3} / \mathrm{MAPbI}_{3-x} \mathrm{Cl}_{x} /$ spiro $/ \mathrm{Au}$ & 10.2 & 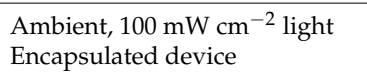 & $\begin{array}{l}60 \% \text { decrease in PCE } \\
\text { after } 175 \mathrm{~h}\end{array}$ & [128] \\
\hline $\begin{array}{l}\mathrm{FTO} / \mathrm{c}-\mathrm{TiO}_{2} / \mathrm{m}-\mathrm{TiO}_{2} \text { and } \\
\mathrm{ZrO}_{2} /(5-\mathrm{AVA})_{x}(\mathrm{MA})_{1-x} \mathrm{PbI}_{3} / \text { carbon film }\end{array}$ & 12.8 & $\begin{array}{l}\text { Room temperature, } \\
1.5 \text { simulated sunlight }\end{array}$ & $1008 \mathrm{~h}$ & [121] \\
\hline $\mathrm{FTO} / \mathrm{c}-\mathrm{TiO}_{2} / \mathrm{MAPbI}_{3-x} \mathrm{Cl}_{x} /$ spiro $/ \mathrm{Au}$ & 10.2 & $\begin{array}{l}\text { Room temperature, } \\
\text { air, humidity }<35 \%\end{array}$ & $\begin{array}{l}15 \text { days, PCE dropped by } \\
\text { one order of magnitude }\end{array}$ & [129] \\
\hline $\mathrm{FTO} / \mathrm{c}-\mathrm{TiO} 2 / \mathrm{MAPbI}_{3-x} \mathrm{Cl}_{x} /$ spiro $/ \mathrm{Au}$ & 16.03 & $\begin{array}{l}\text { Bare device, no encapsulation, } \\
\text { stored under ambient condition }\end{array}$ & $\begin{array}{l}62 \text { days: } 9 \% \text { decrease } \\
\text { in PCE }\end{array}$ & [130] \\
\hline $\begin{array}{l}\mathrm{FTO} / \mathrm{TiO}_{2} \text { nano-rod }+ \\
\mathrm{TiCl}_{4} / \mathrm{MAPbI}_{3-x} \mathrm{Cl}_{x} / \text { spiro } / \mathrm{Au}\end{array}$ & 10.6 & $\begin{array}{l}\text { Room temperature, air, } \\
\text { humidity }<35 \%\end{array}$ & $\begin{array}{l}55 \text { days, } 60 \% \text { of initial } \\
\text { PCE is retained }\end{array}$ & [129] \\
\hline $\mathrm{ITO} / \mathrm{NiO}_{x} /$ perovskite $/ \mathrm{ZnO} / \mathrm{Al}$ & 14.6 & $\begin{array}{l}\text { Air, room temperature, } \\
\text { no encapsulation }\end{array}$ & $\begin{array}{l}60 \text { days, } 90 \% \text { of initial } \\
\text { PCE is retained }\end{array}$ & [85] \\
\hline $\mathrm{FTO} / \mathrm{c}-\mathrm{TiO}_{2} / \mathrm{m}_{-} \mathrm{TiO}_{2} / \mathrm{FEAI}-\mathrm{MAPbI}_{3} /$ spiro $/ \mathrm{Au}$ & & $\begin{array}{l}\text { Air, room temperature, } \\
\text { no encapsulation }\end{array}$ & $\begin{array}{l}120 \text { days, } 92 \% \text { of initial } \\
\text { PCE is retained }\end{array}$ & [131] \\
\hline
\end{tabular}

In order to achieve the main goal of producing cost effective modules of perovskite solar cells, manufacturers must be able to deliver devices with the long term stability. Current products on the market typically have a warranty of 20-25 years (c-silicon solar cells), which suggest that the installation will retain $80 \%$ of its initial output after this time period, corresponding to a system loss of $<1 \% /$ year [132]. The perovskite solar cells demonstrated by Li et al. [122] would pass the temperature or thermal stress test but yet to overcome the moisture ingression issues or pass the damp test. Research conducted over the past couple of years indicates that the major key factors of degradation namely moisture and heat must be addressed to improve the commercial viability of perovskite solar cells and to provide a competitive edge over the currently existing alternatives.

Another important challenge in the development of perovskite solar cells is the concerns with respect to toxicity of Lead $(\mathrm{Pb})$ content in the perovskite material and the environmental concerns of large scale deployment in the future. Recent studies based on life cycle analysis (LCA) and environmental impact analysis (EIA) of perovskite solar cells showed that the lead content in the perovskite materials contributes only to a small proportion on the overall environmental impact during the fabrication or manufacturing process $[133,134]$. The potential lead pollution from the operation of a perovskite PV manufacturing plant of 1-GW capacity is relatively lower when compared with other lead emission sources such as fossil fuels, mining industries, battery technologies and other related electronics [135]. Moreover, recent findings have shown that the perovskite solar cells can be fabricated from the recycled lead from car batteries, [136] which could open up new avenues to reduce the magnitude of lead contamination in the environment from other technologies by providing a viable opportunity to reuse them in perovskite PV industry.

Furthermore, challenges pertaining to the scaling of perovskite solar cell fabrication for large scale deployment should also be addressed in near future for successful commercialization. Thus far, most of the best reported efficiencies $(>20 \%)$ in perovskite PV technology were reported for miniature devices with device area less than $1 \mathrm{~cm}^{2}$. Recently, Chen et al. reported the perovskite solar cells of $1 \mathrm{~cm}^{2}$ with a certified efficiency of $15 \%$ [137]. The authors employed heavily doped inorganic charge extraction layers in planar PSCs to achieve faster carrier extraction as well as depositing a pin-hole free perovskite light absorber layer. Future development of large area perovskite solar cells should also focus on reducing the series resistance losses and conductivity issues with respect to the contacts. In addition, fabrication of high quality perovskite film with uniform microstructure across a large area could pose a significant challenge; consequently, development of other economically viable deposition techniques becomes indispensable for successful commercialization of perovskite 
PV technology. Moreover, most of the best reported perovskite solar cells employ gold and silver as charge collection electrodes which could prove to be uneconomical for large scale deployment and suitable alternative has to be found to mitigate such issues.

\section{Outlook and Conclusions}

The review presented a brief discussion of the progress and developments in the field of perovskite solar cells. The PSC technology has undergone rapid evolution in the past 5-6 years owing to several intriguing factors, including unique optical and electronic properties of halide perovskite materials namely large carrier diffusion lengths, high charge-carrier mobility, low exciton binding energy and bandgap tunability. Further progress in terms of power conversion efficiency (PCE) is predicted via improving the crystal structure quality, grain size distribution of perovskite materials along with uniform surface-coverage and careful control of structural and electronic properties of interfaces within the device. The low exciton binding energy and ambipolar charge transport properties of perovskite films makes them the right candidate for application in tandem cells using other PV-applicable semiconductors, including organic photovoltaics (OPVs), silicon (c-Si or a-Si), copper indium gallium di-selenide (CIGS), etc. $[138,139]$. It is expected that such a combination of materials will enable the creation of low cost and high efficiency $(>25 \%)$ solar cell devices and products [139]. In order to improve the commercial viability of the perovskite PV technology, the prominent issues such as hysteresis and degradation stability (lifetime) has to be addressed from both material and device perspective. Moreover, standard testing protocols have to be developed for testing the devices for accurate evaluation of the performance and lifetime. Overall, perovskite solar cells offer a promising solution for developing the low cost PV technology that could become the game changer of solar industry.

Acknowledgments: The authors gratefully acknowledge the financial support provided by Future Solar Technologies Pty. Ltd. for this work.

Author Contributions: N.K.E. and A.U. designed the structure of the work; N.K.E contributed to all the sections. M.A.M contributed to Sections 4 and 5 and D.W. contributed to Section 6. N.K.E. wrote the paper.

Conflicts of Interest: The authors declare no conflict of interest.

\section{References}

1. Sessolo, M.; Bolink, H.J. Perovskite solar cells join the major league. Science 2015, 350, 917. [CrossRef] [PubMed]

2. Service, R.F. Energy technology: Perovskite solar cells keep on surging. Science 2014, 344, 458. [CrossRef] [PubMed]

3. Sum, T.C.; Mathews, N. Advancements in perovskite solar cells: Photophysics behind the photovoltaics. Energy Environ. Sci. 2014, 7, 2518-2534. [CrossRef]

4. Roldán-Carmona, C.; Malinkiewicz, O.; Soriano, A.; Mínguez Espallargas, G.; Garcia, A.; Reinecke, P.; Kroyer, T.; Dar, M.I.; Nazeeruddin, M.K.; Bolink, H.J. Flexible high efficiency perovskite solar cells. Energy Environ. Sci. 2014, 7, 994-997. [CrossRef]

5. Green, M.A.; Ho-Baillie, A.; Snaith, H.J. The emergence of perovskite solar cells. Nat. Photonics 2014, 8, 506-514. [CrossRef]

6. Grätzel, M. The light and shade of perovskite solar cells. Nat. Mater. 2014, 13, 838-842. [CrossRef] [PubMed]

7. Dualeh, A.; Moehl, T.; Tétreault, N.; Teuscher, J.; Gao, P.; Nazeeruddin, M.K.; Grätzel, M. Impedance Spectroscopic Analysis of Lead Iodide Perovskite-Sensitized Solid-State Solar Cells. ACS Nano 2014, 8, 362-373. [CrossRef] [PubMed]

8. Rose, G.D.P. Fossili Novo. In De Novis Quibusdam Fossilibus Quae in Montibus Uraliis Inveniuntur; AG Schade: Berlin, Germany, 1839.

9. Mitzi, D.B.; Feild, C.A.; Harrison, W.T.A.; Guloy, A.M. Conducting tin halides with a layered organic-based perovskite structure. Nature 1994, 369, 467-469. [CrossRef] 
10. Mitzi, D.B.; Wang, S.; Feild, C.A.; Chess, C.A.; Guloy, A.M. Conducting Layered Organic-inorganic Halides Containing-Oriented Perovskite Sheets. Science 1995, 267, 1473. [CrossRef] [PubMed]

11. Kagan, C.R.; Mitzi, D.B.; Dimitrakopoulos, C.D. Organic-Inorganic Hybrid Materials as Semiconducting Channels in Thin-Film Field-Effect Transistors. Science 1999, 286, 945. [CrossRef] [PubMed]

12. Mitzi, D.B.; Dimitrakopoulos, C.D.; Kosbar, L.L. Structurally tailored organic-inorganic perovskites: Optical properties and solution-processed channel materials for thin-film transistors. Chem. Mater. 2001, 13, 3728-3740. [CrossRef]

13. Mitzi, D.B.; Prikas, M.T.; Chondroudis, K. Thin film deposition of organic-inorganic hybrid materials using a single source thermal ablation technique. Chem. Mater. 1999, 11, 542-544. [CrossRef]

14. Chondroudis, K.; Mitzi, D.B. Electroluminescence from an organic-inorganic perovskite incorporating a quaterthiophene dye within lead halide perovskite layers. Chem. Mater. 1999, 11, 3028-3030. [CrossRef]

15. Liyan, Y.; Alexander, T.B.; David, G.L.; Tao, W. Recent progress and challenges of organometal halide perovskite solar cells. Rep. Prog. Phys. 2016, 79, 026501.

16. Stoumpos, C.C.; Kanatzidis, M.G. Halide Perovskites: Poor Man's High-Performance Semiconductors. Adv. Mater. 2016, 28, 5778-5793. [CrossRef] [PubMed]

17. Jesper Jacobsson, T.; Correa-Baena, J.-P.; Pazoki, M.; Saliba, M.; Schenk, K.; Grätzel, M.; Hagfeldt, A. Exploration of the compositional space for mixed lead halogen perovskites for high efficiency solar cells. Energy Environ. Sci. 2016, 9, 1706-1724. [CrossRef]

18. Yoon, S.; Stamplecoskie, K.G.; Kamat, P.V. How Lead Halide Complex Chemistry Dictates the Composition of Mixed Halide Perovskites. J. Phys. Chem. Lett. 2016, 7, 1368-1373. [CrossRef] [PubMed]

19. Kojima, A.; Teshima, K.; Shirai, Y.; Miyasaka, T. Organometal Halide Perovskites as Visible-Light Sensitizers for Photovoltaic Cells. J. Am. Chem. Soc. 2009, 131, 6050-6051. [CrossRef] [PubMed]

20. Zhu, X. The Perovskite Fever and Beyond. Acc. Chem. Res. 2016, 49, 355-356. [CrossRef] [PubMed]

21. NREL Best Research-Cell Efficiencies. Available online: http://www.nrel.gov/ncpv/images/efficiency_ chart.jpg (accessed on 26 August 2016).

22. Im, J.-H.; Lee, C.-R.; Lee, J.-W.; Park, S.-W.; Park, N.-G. 6.5\% efficient perovskite quantum-dot-sensitized solar cell. Nanoscale 2011, 3, 4088-4093. [CrossRef] [PubMed]

23. Kim, H.-S.; Lee, C.-R.; Im, J.-H.; Lee, K.-B.; Moehl, T.; Marchioro, A.; Moon, S.-J.; Humphry-Baker, R.; Yum, J.-H.; Moser, J.E.; et al. Lead Iodide Perovskite Sensitized All-Solid-State Submicron Thin Film Mesoscopic Solar Cell with Efficiency Exceeding 9\%. Sci. Rep. 2012, 2, 591. [CrossRef] [PubMed]

24. Ball, J.M.; Lee, M.M.; Hey, A.; Snaith, H.J. Low-temperature processed meso-superstructured to thin-film perovskite solar cells. Energy Environ. Sci. 2013, 6, 1739-1743. [CrossRef]

25. Burschka, J.; Pellet, N.; Moon, S.-J.; Humphry-Baker, R.; Gao, P.; Nazeeruddin, M.K.; Gratzel, M. Sequential deposition as a route to high-performance perovskite-sensitized solar cells. Nature 2013, 499, 316-319. [CrossRef] [PubMed]

26. Wang, J.T.-W.; Ball, J.M.; Barea, E.M.; Abate, A.; Alexander-Webber, J.A.; Huang, J.; Saliba, M.; Mora-Sero, I.; Bisquert, J.; Snaith, H.J.; et al. Low-Temperature Processed Electron Collection Layers of Graphene/ $/ \mathrm{TiO}_{2}$ Nanocomposites in Thin Film Perovskite Solar Cells. Nano Lett. 2014, 14, 724-730. [CrossRef] [PubMed]

27. Liu, D.; Kelly, T.L. Perovskite solar cells with a planar heterojunction structure prepared using room-temperature solution processing techniques. Nat. Photon. 2014, 8, 133-138. [CrossRef]

28. Zhou, H.; Chen, Q.; Li, G.; Luo, S.; Song, T.B.; Duan, H.S.; Hong, Z.; You, J.; Liu, Y.; Yang, Y. Interface engineering of highly efficient perovskite solar cells. Science 2014, 345, 542-546. [CrossRef] [PubMed]

29. Yang, W.S.; Noh, J.H.; Jeon, N.J.; Kim, Y.C.; Ryu, S.; Seo, J.; Seok, S.I. High-performance photovoltaic perovskite layers fabricated through intramolecular exchange. Science 2015, 348, 1234-1237. [CrossRef] [PubMed]

30. Saliba, M.; Matsui, T.; Seo, J.-Y.; Domanski, K.; Correa-Baena, J.-P.; Nazeeruddin, M.K.; Zakeeruddin, S.M.; Tress, W.; Abate, A.; Hagfeldt, A.; et al. Cesium-containing triple cation perovskite solar cells: Improved stability, reproducibility and high efficiency. Energy Environ. Sci. 2016, 9, 1989-1997. [CrossRef] [PubMed]

31. Shockley, W.; Queisser, H.J. Detailed Balance Limit of Efficiency of p-n Junction Solar Cells. J. Appl. Phys. 1961, 32, 510-519. [CrossRef]

32. Yin, W.-J.; Yang, J.-H.; Kang, J.; Yan, Y.; Wei, S.-H. Halide perovskite materials for solar cells: A theoretical review. J. Mater. Chem. A 2015, 3, 8926-8942. [CrossRef] 
33. Lin, Q.; Armin, A.; Nagiri, R.C.R.; Burn, P.L.; Meredith, P. Electro-optics of perovskite solar cells. Nat. Photon. 2015, 9, 106-112. [CrossRef]

34. Jeon, N.J.; Noh, J.H.; Yang, W.S.; Kim, Y.C.; Ryu, S.; Seo, J.; Seok, S.I. Compositional engineering of perovskite materials for high-performance solar cells. Nature 2015, 517, 476-480. [CrossRef] [PubMed]

35. DeQuilettes, D.W.; Vorpahl, S.M.; Stranks, S.D.; Nagaoka, H.; Eperon, G.E.; Ziffer, M.E.; Snaith, H.J.; Ginger, D.S. Impact of microstructure on local carrier lifetime in perovskite solar cells. Science 2015, 348, 683-686. [CrossRef] [PubMed]

36. Jain, A.; Shin, Y.; Persson, K.A. Computational predictions of energy materials using density functional theory. Nat. Rev. Mater. 2016, 1, 15004. [CrossRef]

37. Stoumpos, C.C.; Malliakas, C.D.; Kanatzidis, M.G. Semiconducting Tin and Lead Iodide Perovskites with Organic Cations: Phase Transitions, High Mobilities, and Near-Infrared Photoluminescent Properties. Inorg. Chem. 2013, 52, 9019-9038. [CrossRef] [PubMed]

38. Baikie, T.; Fang, Y.; Kadro, J.M.; Schreyer, M.; Wei, F.; Mhaisalkar, S.G.; Graetzel, M.; White, T.J. Synthesis and crystal chemistry of the hybrid perovskite (CH3NH3) PbI3 for solid-state sensitised solar cell applications. J. Mater. Chem. A 2013, 1, 5628-5641. [CrossRef]

39. Manser, J.S.; Christians, J.A.; Kamat, P.V. Intriguing optoelectronic properties of metal halide perovskites. Chem. Rev. 2016. [CrossRef] [PubMed]

40. Wang, D.; Wright, M.; Elumalai, N.K.; Uddin, A. Stability of perovskite solar cells. Sol. Energy Mater. Sol. Cells 2016, 147, 255-275. [CrossRef]

41. Feng, J.; Xiao, B. Crystal structures, optical properties, and effective mass tensors of $\mathrm{CH} 3 \mathrm{NH} 3 \mathrm{PbX} 3$ ( $\mathrm{X}=\mathrm{I}$ and Br) phases predicted from HSE06. J. Phys. Chem. Lett. 2014, 5, 1278-1282. [CrossRef] [PubMed]

42. Fan, Z.; Sun, K.; Wang, J. Perovskites for photovoltaics: A combined review of organic-inorganic halide perovskites and ferroelectric oxide perovskites. J. Mater. Chem. A 2015, 3, 18809-18828. [CrossRef]

43. Kawamura, Y.; Mashiyama, H.; Hasebe, K. Structural Study on Cubic-Tetragonal Transition of CH3NH3PbI3. J. Phys. Soc. Jpn. 2002, 71, 1694-1697. [CrossRef]

44. Pang, S.; Hu, H.; Zhang, J.; Lv, S.; Yu, Y.; Wei, F.; Qin, T.; Xu, H.; Liu, Z.; Cui, G. NH2CH=NH2PbI3: An Alternative Organolead Iodide Perovskite Sensitizer for Mesoscopic Solar Cells. Chem. Mater. 2014, 26, 1485-1491. [CrossRef]

45. Gottesman, R.; Gouda, L.; Kalanoor, B.S.; Haltzi, E.; Tirosh, S.; Rosh-Hodesh, E.; Tischler, Y.; Zaban, A.; Quarti, C.; Mosconi, E.; et al. Photoinduced Reversible Structural Transformations in Free-Standing CH3NH3PbI3 Perovskite Films. J. Phys. Chem. Lett. 2015, 6, 2332-2338. [CrossRef] [PubMed]

46. Koutselas, I.B.; Ducasse, L.; Papavassiliou, G.C. Electronic properties of three- and low-dimensional semiconducting materials with $\mathrm{Pb}$ halide and $\mathrm{Sn}$ halide units. J. Phys. Condens. Matter 1996, 8, 1217. [CrossRef]

47. Umari, P.; Mosconi, E.; de Angelis, F. Relativistic GW calculations on CH3NH3PbI3 and CH3NH3SnI3 Perovskites for Solar Cell Applications. Sci. Rep. 2014, 4, 4467. [CrossRef] [PubMed]

48. Li, C.; Lu, X.; Ding, W.; Feng, L.; Gao, Y.; Guo, Z. Formability of ABX3 (X = F, Cl, Br, I) halide perovskites. Acta Crystallogr. Sec. B Struct. Sci. 2008, 64, 702-707. [CrossRef] [PubMed]

49. Kieslich, G.; Sun, S.; Cheetham, A.K. An extended Tolerance Factor approach for organic-inorganic perovskites. Chem. Sci. 2015, 6, 3430-3433. [CrossRef]

50. Travis, W.; Glover, E.N.K.; Bronstein, H.; Scanlon, D.O.; Palgrave, R.G. On the application of the tolerance factor to inorganic and hybrid halide perovskites: A revised system. Chem. Sci. 2016, 7, 4548-4556. [CrossRef]

51. Stoumpos, C.C.; Kanatzidis, M.G. The Renaissance of Halide Perovskites and Their Evolution as Emerging Semiconductors. Acc. Chem. Res. 2015, 48, 2791-2802. [CrossRef] [PubMed]

52. Walsh, A.; Watson, G.W. The origin of the stereochemically active $\mathrm{Pb}$ (II) lone pair: $\mathrm{DFT}$ calculations on $\mathrm{PbO}$ and PbS. J. Solid State Chem. 2005, 178, 1422-1428. [CrossRef]

53. Walsh, A.; Payne, D.J.; Egdell, R.G.; Watson, G.W. Stereochemistry of post-transition metal oxides: Revision of the classical lone pair model. Chem. Soc. Rev. 2011, 40, 4455-4463. [CrossRef] [PubMed]

54. Walsh, A. Principles of Chemical Bonding and Band Gap Engineering in Hybrid Organic-Inorganic Halide Perovskites. J. Phys. Chem. C Nanomater Interfaces 2015, 119, 5755-5760. [CrossRef] [PubMed]

55. Filip, M.R.; Eperon, G.E.; Snaith, H.J.; Giustino, F. Steric engineering of metal-halide perovskites with tunable optical band gaps. Nat. Commun. 2014, 5, 5757. [CrossRef] [PubMed] 
56. Yin, W.-J.; Shi, T.; Yan, Y. Unique Properties of Halide Perovskites as Possible Origins of the Superior Solar Cell Performance. Adv. Mater. 2014, 26, 4653-4658. [CrossRef] [PubMed]

57. Edri, E.; Kirmayer, S.; Henning, A.; Mukhopadhyay, S.; Gartsman, K.; Rosenwaks, Y.; Hodes, G.; Cahen, D. Why Lead Methylammonium Tri-Iodide Perovskite-Based Solar Cells Require a Mesoporous Electron Transporting Scaffold (but Not Necessarily a Hole Conductor). Nano Lett. 2014, 14, 1000-1004. [CrossRef] [PubMed]

58. Yun, J.S.; Ho-Baillie, A.; Huang, S.; Woo, S.H.; Heo, Y.; Seidel, J.; Huang, F.; Cheng, Y.-B.; Green, M.A. Benefit of Grain Boundaries in Organic-Inorganic Halide Planar Perovskite Solar Cells. J. Phys. Chem. Lett. 2015, 6, 875-880. [CrossRef] [PubMed]

59. Miyasaka, T. Perovskite Photovoltaics: Rare Functions of Organo Lead Halide in Solar Cells and Optoelectronic Devices. Chem. Lett. 2015, 44, 720-729. [CrossRef]

60. Wang, Q.; Bi, C.; Huang, J. Doped hole transport layer for efficiency enhancement in planar heterojunction organolead trihalide perovskite solar cells. Nano Energy 2015, 15, 275-280. [CrossRef]

61. Milot, R.L.; Eperon, G.E.; Snaith, H.J.; Johnston, M.B.; Herz, L.M. Temperature-Dependent Charge-Carrier Dynamics in CH3NH3PbI3 Perovskite Thin Films. Adv. Funct. Mater. 2015, 25, 6218-6227. [CrossRef]

62. Wehrenfennig, C.; Eperon, G.E.; Johnston, M.B.; Snaith, H.J.; Herz, L.M. High Charge Carrier Mobilities and Lifetimes in Organolead Trihalide Perovskites. Adv. Mater. 2014, 26, 1584-1589. [CrossRef] [PubMed]

63. Buin, A.; Pietsch, P.; Xu, J.; Voznyy, O.; Ip, A.H.; Comin, R.; Sargent, E.H. Materials Processing Routes to Trap-Free Halide Perovskites. Nano Lett. 2014, 14, 6281-6286. [CrossRef] [PubMed]

64. Stranks, S.D.; Eperon, G.E.; Grancini, G.; Menelaou, C.; Alcocer, M.J. P.; Leijtens, T.; Herz, L.M.; Petrozza, A.; Snaith, H.J. Electron-Hole Diffusion Lengths Exceeding 1 Micrometer in an Organometal Trihalide Perovskite Absorber. Science 2013, 342, 341-344. [CrossRef] [PubMed]

65. Xing, G.; Mathews, N.; Sun, S.; Lim, S.S.; Lam, Y.M. Long-range balanced electron-and hole-transport lengths in organic-inorganic CH3NH3PbI3. Science 2013, 342, 344-347. [CrossRef] [PubMed]

66. Sheng, R.; Ho-Baillie, A.; Huang, S.; Chen, S.; Wen, X.; Hao, X.; Green, M.A. Methylammonium Lead Bromide Perovskite-Based Solar Cells by Vapor-Assisted Deposition. J. Phys. Chem. C 2015, 119, 3545-3549. [CrossRef]

67. Eperon, G.E.; Stranks, S.D.; Menelaou, C.; Johnston, M.B.; Herz, L.M.; Snaith, H.J. Formamidinium lead trihalide: A broadly tunable perovskite for efficient planar heterojunction solar cells. Energy Environ. Sci. 2014, 7, 982-988. [CrossRef]

68. Rehman, W.; Milot, R.L.; Eperon, G.E.; Wehrenfennig, C.; Boland, J.L.; Snaith, H.J.; Johnston, M.B.; Herz, L.M. Charge-Carrier Dynamics and Mobilities in Formamidinium Lead Mixed-Halide Perovskites. Adv. Mater. 2015, 27, 7938-7944. [CrossRef] [PubMed]

69. Noel, N.K.; Stranks, S.D.; Abate, A.; Wehrenfennig, C.; Guarnera, S.; Haghighirad, A.-A.; Sadhanala, A.; Eperon, G.E.; Pathak, S.K.; Johnston, M.B.; et al. Lead-free organic-inorganic tin halide perovskites for photovoltaic applications. Energy Environ. Sci. 2014, 7, 3061-3068. [CrossRef]

70. Song, Z.; Watthage, S.C.; Phillips, A.B.; Heben, M.J. Pathways toward high-performance perovskite solar cells: Review of recent advances in organo-metal halide perovskites for photovoltaic applications. PHOTOE 2016, 6, 022001. [CrossRef]

71. Lee, M.M.; Teuscher, J.; Miyasaka, T.; Murakami, T.N.; Snaith, H.J. Efficient Hybrid Solar Cells Based on Meso-Superstructured Organometal Halide Perovskites. Science 2012, 338, 643. [CrossRef] [PubMed]

72. Liu, T.; Chen, K.; Hu, Q.; Zhu, R.; Gong, Q. Inverted Perovskite Solar Cells: Progresses and Perspectives. Adv. Energy Mater. 2016, 7, 3994-3999. [CrossRef]

73. Yin, W.; Pan, L.; Yang, T.; Liang, Y. Recent Advances in Interface Engineering for Planar Heterojunction Perovskite Solar Cells. Molecules 2016, 21, 837. [CrossRef] [PubMed]

74. Kim, H.; Lim, K.-G.; Lee, T.-W. Planar heterojunction organometal halide perovskite solar cells: Roles of interfacial layers. Energy Environ. Sci. 2016, 9, 12-30. [CrossRef]

75. Collavini, S.; Kosta, I.; Völker, S.F.; Cabanero, G.; Grande, H.J.; Tena-Zaera, R.; Delgado, J.L. Efficient regular perovskite solar cells based on pristine [70]fullerene as electron-selective contact. ChemSusChem 2016, 9, 1263-1270. [CrossRef] [PubMed]

76. Pascual, J.; Kosta, I.; Tuyen Ngo, T.; Chuvilin, A.; Cabanero, G.; Grande, H.J.; Barea, E.M.; Mora-Seró, I.; Delgado, J.L.; Tena-Zaera, R. Electron Transport Layer-Free Solar Cells Based on Perovskite-Fullerene Blend Films with Enhanced Performance and Stability. ChemSusChem 2016, 9, 2679-2685. [CrossRef] [PubMed] 
77. Heo, J.H.; Song, D.H.; Patil, B.R.; Im, S.H. Recent Progress of Innovative Perovskite Hybrid Solar Cells. Isr. J. Chem. 2015, 55, 966-977. [CrossRef]

78. Aharon, S.; Cohen, B.E.; Etgar, L. Hybrid Lead Halide Iodide and Lead Halide Bromide in Efficient Hole Conductor Free Perovskite Solar Cell. J. Phys. Chem. C 2014, 118, 17160-17165. [CrossRef]

79. Xiao, Z.; Bi, C.; Shao, Y.; Dong, Q.; Wang, Q.; Yuan, Y.; Wang, C.; Gao, Y.; Huang, J. Efficient, high yield perovskite photovoltaic devices grown by interdiffusion of solution-processed precursor stacking layers. Energy Environ. Sci. 2014, 7, 2619-2623. [CrossRef]

80. Deng, Y.; Peng, E.; Shao, Y.; Xiao, Z.; Dong, Q.; Huang, J. Scalable fabrication of efficient organolead trihalide perovskite solar cells with doctor-bladed active layers. Energy Environ. Sci. 2015, 8, 1544-1550. [CrossRef]

81. Hwang, K.; Jung, Y.-S.; Heo, Y.-J.; Scholes, F.H.; Watkins, S.E.; Subbiah, J.; Jones, D.J.; Kim, D.-Y.; Vak, D. Toward Large Scale Roll-to-Roll Production of Fully Printed Perovskite Solar Cells. Adv. Mater. 2015, 27, 1241-1247. [CrossRef] [PubMed]

82. Liu, M.; Johnston, M.B.; Snaith, H.J. Efficient planar heterojunction perovskite solar cells by vapour deposition. Nature 2013, 501, 395-398. [CrossRef] [PubMed]

83. Bai, S.; Wu, Z.; Wu, X.; Jin, Y.; Zhao, N.; Chen, Z.; Mei, Q.; Wang, X.; Ye, Z.; Song, T.; Liu, R.; et al. High-performance planar heterojunction perovskite solar cells: Preserving long charge carrier diffusion lengths and interfacial engineering. Nano Res. 2014, 7, 1749-1758. [CrossRef]

84. Roldan-Carmona, C.; Gratia, P.; Zimmermann, I.; Grancini, G.; Gao, P.; Graetzel, M.; Nazeeruddin, M.K. High efficiency methylammonium lead triiodide perovskite solar cells: The relevance of non-stoichiometric precursors. Energy Environ. Sci. 2015, 8, 3550-3556. [CrossRef]

85. You, J.; Meng, L.; Song, T.-B.; Guo, T.-F.; Yang, Y.; Chang, W.-H.; Hong, Z.; Chen, H.; Zhou, H.; Chen, Q.; et al. Improved air stability of perovskite solar cells via solution-processed metal oxide transport layers. Nat. Nanotechol. 2016, 11, 75-81. [CrossRef] [PubMed]

86. Ahn, N.; Son, D.-Y.; Jang, I.-H.; Kang, S.M.; Choi, M.; Park, N.-G. Highly reproducible perovskite solar cells with average efficiency of $18.3 \%$ and best efficiency of $19.7 \%$ fabricated via lewis base adduct of lead(ii) iodide. J. Am. Chem. Soc. 2015, 137, 8696-8699. [CrossRef] [PubMed]

87. Li, W.; Fan, J.; Li, J.; Mai, Y.; Wang, L. Controllable Grain Morphology of Perovskite Absorber Film by Molecular Self-Assembly toward Efficient Solar Cell Exceeding 17\%. J. Am. Chem. Soc. 2015, 137, 10399-10405. [CrossRef] [PubMed]

88. Nie, W.; Tsai, H.; Asadpour, R.; Blancon, J.-C.; Neukirch, A.J.; Gupta, G.; Crochet, J.J.; Chhowalla, M.; Tretiak, S.; Alam, M.A.; et al. High-efficiency solution-processed perovskite solar cells with millimeter-scale grains. Science 2015, 347, 522-525. [CrossRef] [PubMed]

89. Heo, J.H.; Han, H.J.; Kim, D.; Ahn, T.K.; Im, S.H. Hysteresis-less inverted CH3NH3PbI3 planar perovskite hybrid solar cells with 18.1\% power conversion efficiency. Energy Environ. Sci. 2015, 8, 1602-1608. [CrossRef]

90. Correa Baena, J.P.; Steier, L.; Tress, W.; Saliba, M.; Neutzner, S.; Matsui, T.; Giordano, F.; Jacobsson, T.J.; Srimath Kandada, A.R.; Zakeeruddin, S.M.; et al. Highly efficient planar perovskite solar cells through band alignment engineering. Energy Environ. Sci. 2015, 8, 2928-2934. [CrossRef]

91. Chueh, C.-C.; Li, C.-Z.; Jen, A.K. Y. Recent progress and perspective in solution-processed interfacial materials for efficient and stable polymer and organometal perovskite solar cells. Energy Environ. Sci. 2015, 8, 1160-1189. [CrossRef]

92. Unger, E.L.; Hoke, E.T.; Bailie, C.D.; Nguyen, W.H.; Bowring, A.R.; Heumüller, T.; Christoforo, M.G.; McGehee, M.D. Hysteresis and transient behavior in current-voltage measurements of hybrid-perovskite absorber solar cells. Energy Environ. Sci. 2014, 7, 3690-3698. [CrossRef]

93. Gottesman, R.; Haltzi, E.; Gouda, L.; Tirosh, S.; Bouhadana, Y.; Zaban, A.; Mosconi, E.; de Angelis, F. Extremely Slow Photoconductivity Response of CH3NH3PbI3 Perovskites Suggesting Structural Changes under Working Conditions. J. Phys. Chem. Lett. 2014, 5, 2662-2669. [CrossRef] [PubMed]

94. Chen, H.-W.; Sakai, N.; Ikegami, M.; Miyasaka, T. Emergence of Hysteresis and Transient Ferroelectric Response in Organo-Lead Halide Perovskite Solar Cells. J. Phys. Chem. Lett. 2015, 6, 164-169. [PubMed]

95. Elumalai, N.K.; Uddin, A. Hysteresis in organic-inorganic hybrid perovskite solar cells. Sol. Energy Mater. Sol. Cells 2016, 157, 476-509. [CrossRef]

96. McGehee, M.D. Perovskite solar cells: Continuing to soar. Nat. Mater. 2014, 13, 845-846. [CrossRef] [PubMed]

97. Butler, K.T.; Frost, J.M.; Walsh, A. Ferroelectric materials for solar energy conversion: Photoferroics revisited. Energy Environ. Sci. 2014, 8, 838-848. [CrossRef] 
98. Fan, Z.; Xiao, J.; Sun, K.; Chen, L.; Hu, Y.; Ouyang, J.; Ong, K.P.; Zeng, K.; Wang, J. Ferroelectricity of CH3NH3PbI3 Perovskite. J. Phys. Chem. Lett. 2015, 6, 1155-1161. [CrossRef] [PubMed]

99. Azpiroz, J.M.; Mosconi, E.; Bisquert, J.; De Angelis, F. Defect migration in methylammonium lead iodide and its role in perovskite solar cell operation. Energy Environ. Sci. 2015, 8, 2118-2127. [CrossRef]

100. Leguy, A.M.; Frost, J.M.; McMahon, A.P.; Sakai, V.G.; Kochelmann, W.; Law, C.; Li, X.; Foglia, F.; Walsh, A.; O'Regan, B.C.; et al. The dynamics of methylammonium ions in hybrid organic-inorganic perovskite solar cells. Nat. Commun. 2015, 6, 7124. [CrossRef] [PubMed]

101. Bastiani, M.; Dell'Erba, G.; Gandini, M.; D’Innocenzo, V.; Neutzner, S.; Kandada, A.; Grancini, G.; Binda, M.; Prato, M.; Ball, J.M.; et al. Ion Migration and the Role of Preconditioning Cycles in the Stabilization of the J-V Characteristics of Inverted Hybrid Perovskite Solar Cells. Adv. Energy Mater. 2015, 6, 1501453. [CrossRef]

102. Zhang, Y.; Liu, M.; Eperon, G.E.; Leijtens, T.C.; McMeekin, D.; Saliba, M.; Zhang, W.; de Bastiani, M.; Petrozza, A.; Herz, L.M.; et al. Charge selective contacts, mobile ions and anomalous hysteresis in organic-inorganic perovskite solar cells. Mater. Horiz. 2015, 2, 315-322. [CrossRef]

103. Van Reenen, S.; Kemerink, M.; Snaith, H.J. Modeling Anomalous Hysteresis in Perovskite Solar Cells. J. Phys. Chem. Lett. 2015, 6, 3808-3814. [CrossRef] [PubMed]

104. Almora, O.; Zarazua, I.; Mas-Marza, E.; Mora-Sero, I.; Bisquert, J.; Garcia-Belmonte, G. Capacitive Dark Currents, Hysteresis, and Electrode Polarization in Lead Halide Perovskite Solar Cells. J. Phys. Chem. Lett. 2015, 6, 1645-1652. [CrossRef] [PubMed]

105. Christians, J.A.; Manser, J.S.; Kamat, P.V. Best Practices in Perovskite Solar Cell Efficiency Measurements. Avoiding the Error of Making Bad Cells Look Good. J. Phys. Chem. Lett. 2015, 6, 852-857. [CrossRef] [PubMed]

106. Haillant, O. Accelerated weathering testing principles to estimate the service life of organic PV modules. Sol. Energy Mater. Sol. Cells 2011, 95, 1284-1292. [CrossRef]

107. Berhe, T.; Su, W.-N.; Chen, C.-H.; Pan, C.-J.; Cheng, J.-H.; Chen, H.-M.; Tsai, M.-C.; Chen, L.-Y.; Dubale, A.; Hwang, B.-J. Organometal halide perovskite solar cells: Degradation and stability. Energy Environ. Sci. 2016, 9, 323-356. [CrossRef]

108. Leijtens, T.; Eperon, G.E.; Noel, N.K.; Habisreutinger, S.N.; Petrozza, A.; Snaith, H.J. Stability of metal halide perovskite solar cells. Adv. Energy Mater. 2015, 5. [CrossRef]

109. Leo, K. Perovskite photovoltaics: Signs of stability. Nat. Nanotechnol. 2015, 10, 574-575. [CrossRef] [PubMed]

110. Rong, Y.; Liu, L.; Mei, A.; Li, X.; Han, H. Beyond Efficiency: The Challenge of Stability in Mesoscopic Perovskite Solar Cells. Adv. Energy Mater. 2015, 5, 1501066. [CrossRef]

111. von Hauff, E.; Lira-Cantu, M.; Brown, T.M.; Hoppe, H. Emerging thin-film photovoltaics: Stabilize or perish. Adv. Energy Mater. 2015, 5. [CrossRef]

112. Zhao, X.; Park, N.-G. Stability Issues on Perovskite Solar Cells. Photonics 2015, 2, 1139-1157. [CrossRef]

113. Shahbazi, M.; Wang, H. Progress in research on the stability of organometal perovskite solar cells. Sol. Energy 2016, 123, 74-87. [CrossRef]

114. Tiep, N.H.; Ku, Z.; Fan, H.J. Recent Advances in Improving the Stability of Perovskite Solar Cells. Adv. Energy Mater. 2016, 6, 1501420. [CrossRef]

115. Navas, J.; Sánchez-Coronilla, A.; Gallardo, J.J.; Martín, E.I.; Hernández, N.C.; Alcántara, R.; Fernández-Lorenzo, C.; Martín-Calleja, J. Revealing the role of $\mathrm{Pb}(2+)$ in the stability of organic-inorganic hybrid perovskite $\mathrm{CH} 3 \mathrm{NH} 3 \mathrm{~Pb} 1-x \mathrm{CdxI}$ : An experimental and theoretical study. Phys. Chem. Chem. Phys. 2015, 17, 23886-23896. [CrossRef] [PubMed]

116. Qin, C.; Matsushima, T.; Fujihara, T.; Potscavage, W.J.; Adachi, C. Degradation mechanisms of solution-processed planar perovskite solar cells: Thermally stimulated current measurement for analysis of carrier traps. Adv. Mater. 2015. [CrossRef] [PubMed]

117. Philippe, B.; Park, B.-W.; Lindblad, R.; Oscarsson, J.; Ahmadi, S.; Johansson, E.M.J.; Rensmo, H. Chemical and Electronic Structure Characterization of Lead Halide Perovskites and Stability Behavior under Different Exposures-A Photoelectron Spectroscopy Investigation. Chem. Mater. 2015, 27, 1720-1731. [CrossRef]

118. Supasai, T.; Rujisamphan, N.; Ullrich, K.; Chemseddine, A.; Dittrich, T. Formation of a passivating $\mathrm{CH} 3 \mathrm{NH} 3 \mathrm{PbI} 3 / \mathrm{PbI} 2$ interface during moderate heating of $\mathrm{CH} 3 \mathrm{NH} 3 \mathrm{PbI} 3$ layers. Appl. Phys. Lett. 2013, 103, 183906. [CrossRef] 
119. Williams, S.T.; Zuo, F.; Chueh, C.-C.; Liao, C.-Y.; Liang, P.-W.; Jen, A.K.Y. Role of Chloride in the Morphological Evolution of Organo-Lead Halide Perovskite Thin Films. ACS Nano 2014, 8, 10640-10654. [CrossRef] [PubMed]

120. Li, X.; Ibrahim Dar, M.; Yi, C.; Luo, J.; Tschumi, M.; Zakeeruddin, S.M.; Nazeeruddin, M.K.; Han, H.; Grätzel, M. Improved performance and stability of perovskite solar cells by crystal crosslinking with alkylphosphonic acid $\omega$-ammonium chlorides. Nat. Chem. 2015, 7, 703-711. [CrossRef] [PubMed]

121. Mei, A.; Li, X.; Liu, L.; Ku, Z.; Liu, T.; Rong, Y.; Xu, M.; Hu, M.; Chen, J.; Yang, Y.; Grätzel, M.; Han, H. A hole-conductor-free, fully printable mesoscopic perovskite solar cell with high stability. Science 2014, 345, 295. [CrossRef] [PubMed]

122. Li, X.; Tschumi, M.; Han, H.; Babkair, S.S.; Alzubaydi, R.A.; Ansari, A.A.; Habib, S.S.; Nazeeruddin, M.K.; Zakeeruddin, S.M.; Grätzel, M. Outdoor Performance and Stability under Elevated Temperatures and Long-Term Light Soaking of Triple-Layer Mesoporous Perovskite Photovoltaics. Energy Technol. 2015, 3, 551-555. [CrossRef]

123. Krebs, F.C. Encapsulation of polymer photovoltaic prototypes. Sol. Energy Mater. Sol. Cells 2006, 90, 3633-3643. [CrossRef]

124. Hauch, J.A.; Schilinsky, P.; Choulis, S.A.; Childers, R.; Biele, M.; Brabec, C.J. Flexible organic P3HT:PCBM bulk-heterojunction modules with more than 1 year outdoor lifetime. Sol. Energy Mater. Sol. Cells 2008, 92, 727-731. [CrossRef]

125. Kato, Y.; Ono, L.K.; Lee, M.V.; Wang, S.; Raga, S.R.; Qi, Y. Silver iodide formation in methyl ammonium lead iodide perovskite solar cells with silver top electrodes. Adv. Mater. Interfaces 2015, 2. [CrossRef]

126. Habisreutinger, S.N.; Leijtens, T.; Eperon, G.E.; Stranks, S.D.; Nicholas, R.J.; Snaith, H.J. Carbon Nanotube/Polymer Composites as a Highly Stable Hole Collection Layer in Perovskite Solar Cells. Nano Lett. 2014, 14, 5561-5568. [CrossRef] [PubMed]

127. Badia, L.; Mas-Marzá, E.; Sánchez, R.S.; Barea, E.M.; Bisquert, J.; Mora-Seró, I. New iridium complex as additive to the spiro-OMeTAD in perovskite solar cells with enhanced stability. APL Mater. 2014, 2, 081507. [CrossRef]

128. Guarnera, S.; Abate, A.; Zhang, W.; Foster, J.M.; Richardson, G.; Petrozza, A.; Snaith, H.J. Improving the Long-Term Stability of Perovskite Solar Cells with a Porous $\mathrm{Al}_{2} \mathrm{O}_{3}$ Buffer Layer. J. Phys. Chem. Lett. 2015, 6, 432-437. [CrossRef] [PubMed]

129. Fakharuddin, A.; Di Giacomo, F.; Ahmed, I.; Wali, Q.; Brown, T.M.; Jose, R. Role of morphology and crystallinity of nanorod and planar electron transport layers on the performance and long term durability of perovskite solar cells. J. Power Sources 2015, 283, 61-67. [CrossRef]

130. Yang, D.; Yang, Z.; Qin, W.; Zhang, Y.; Liu, S.; Li, C. Alternating precursor layer deposition for highly stable perovskite films towards efficient solar cells using vacuum deposition. J. Mater. Chem. A 2015, 3, 9401-9405. [CrossRef]

131. Bi, D.; Gao, P.; Scopelliti, R.; Oveisi, E.; Luo, J.; Grätzel, M.; Hagfeldt, A.; Nazeeruddin, M.K. High-Performance Perovskite Solar Cells with Enhanced Environmental Stability Based on Amphiphile-Modified CH3NH3PbI3. Adv. Mater. 2016, 28, 2910-2915. [CrossRef] [PubMed]

132. Roesch, R.; Faber, T.; von Hauff, E.; Brown, T.M.; Lira-Cantu, M.; Hoppe, H. Procedures and practices for evaluating thin-film solar cell stability. Adv. Energy Mater. 2015, 5. [CrossRef]

133. Gong, J.; Darling, S.B.; You, F. Perovskite photovoltaics: Life-cycle assessment of energy and environmental impacts. Energy Environ. Sci. 2015, 8, 1953-1968. [CrossRef]

134. Espinosa, N.; Serrano-Luján, L.; Urbina, A.; Krebs, F.C. Solution and vapour deposited lead perovskite solar cells: Ecotoxicity from a life cycle assessment perspective. Sol. Energy Mater. Sol. Cells 2015, 137, 303-310. [CrossRef]

135. Hailegnaw, B.; Kirmayer, S.; Edri, E.; Hodes, G.; Cahen, D. Rain on Methylammonium Lead Iodide Based Perovskites: Possible Environmental Effects of Perovskite Solar Cells. J. Phys. Chem. Lett. 2015, 6, 1543-1547. [CrossRef] [PubMed]

136. Chen, P.-Y.; Qi, J.; Klug, M.T.; Dang, X.; Hammond, P.T.; Belcher, A.M. Environmentally responsible fabrication of efficient perovskite solar cells from recycled car batteries. Energy Environ. Sci. 2014, 7, 3659-3665. [CrossRef] 
137. Chen, W.; Wu, Y.; Yue, Y.; Liu, J.; Zhang, W.; Yang, X.; Chen, H.; Bi, E.; Ashraful, I.; Grätzel, M.; et al. Efficient and stable large-area perovskite solar cells with inorganic charge extraction layers. Science 2015, 350, 944. [CrossRef] [PubMed]

138. McMeekin, D.P.; Sadoughi, G.; Rehman, W.; Eperon, G.E.; Saliba, M.; Hörantner, M.T.; Haghighirad, A.; Sakai, N.; Korte, L.; Rech, B.; et al. A mixed-cation lead mixed-halide perovskite absorber for tandem solar cells. Science 2016, 351, 151-155. [CrossRef] [PubMed]

139. Bailie, C.D.; Christoforo, M.G.; Mailoa, J.P.; Bowring, A.R.; Unger, E.L.; Nguyen, W.H.; Burschka, J.; Pellet, N.; Lee, J.Z.; Gratzel, M.; et al. Semi-transparent perovskite solar cells for tandems with silicon and CIGS. Energy Environ. Sci. 2015, 8, 956-963. [CrossRef]

C 2016 by the authors; licensee MDPI, Basel, Switzerland. This article is an open access article distributed under the terms and conditions of the Creative Commons Attribution (CC-BY) license (http:/ / creativecommons.org/licenses/by/4.0/). 